\title{
CAMA
}

Centre for Applied Macroeconomic Analysis

\section{What has publishing inflation forecasts accomplished? Central banks and their competitors}

\section{CAMA Working Paper 33/2017 April 2017}

\section{Pierre L. Siklos}

Wilfrid Laurier University, Canada and

Centre for Applied Macroeconomic Analysis, ANU

\section{Address for correspondence:}

(E) cama.admin@anu.edu.au

ISSN 2206-0332

The Centre for Applied Macroeconomic Analysis in the Crawford School of Public Policy has been established to build strong links between professional macroeconomists. It provides a forum for quality macroeconomic research and discussion of policy issues between academia, government and the private sector.

The Crawford School of Public Policy is the Australian National University's public policy school, serving and influencing Australia, Asia and the Pacific through advanced policy research, graduate and executive education, and policy impact. 
What Has Publishing Inflation Forecasts Accomplished?

Central Banks And Their Competitors

\author{
Pierre L. Siklos ${ }^{*}$ \\ Lazaridis School of Business and Economics \\ Balsillie School of International Affairs \\ Wilfrid Laurier University \\ and Centre for Applied Macroeconomic Analysis (CAMA)
}

[THIS DRAFT: MARCH 2017]

\begin{abstract}
* An earlier version of this paper circulated under the title: "Forecast Disagreement and the Inflation Outlook: New International Evidence” which appears as Discussion Paper 2016-E-3, Institute for Economic and Monetary Studies, Bank of Japan, March. Research for this paper was undertaken while I was National Fellow at the Hoover Institution and a Visiting Scholar at the Institute for Monetary and Economic Studies, Bank of Japan. I am grateful to both for their financial support. I am also grateful to several central banks, the Bank for International Settlements, and the Bank of Japan for their assistance in providing me with some of the data collected for this study. Earlier versions of this paper were presented at an invited session of the
\end{abstract}


$8^{\text {th }}$ International Conference in Computational and Financial Econometrics (Pisa, Italy), the Japanese Centre for Economic Research, the Bank of Japan, the University of Stellenbosch and the Zürich Workshop on the Economics of Central Banking. I am also grateful to two anonymous referee for comments on earlier drafts. This chapter is prepared for the Oxford University Press Handbook of Central Banking (David Mayes, Pierre Siklos, and Jan-Egbert Sturm, Editors). 


\section{Introduction}

Perhaps one of the most important elements in efforts by central banks around the world to become more transparent has been their willingness to provide the public with numerical expressions of the economic outlook. Moreover, since these same central banks have staked a considerable part of their reputation on their ability to maintain low and stable inflation rates, naturally there has been considerable emphasis on forecasts of inflation. This is, of course, especially true in so-called inflation targeting economies because their remit is explicitly based on a numerical objective. Nevertheless, a case can also be made that a similar explanation holds for many other central banks either because price stability is mandated or because there is a general understanding, often publicized by central banks themselves, of what inflation rate is being aimed for.

The behavior of inflation worldwide over the past decade or so, especially since the onset of the ‘Global Financial Crisis’ (GFC), has arguably been the focus of intense debate, especially in monetary policy circles. The profession, as well as central bankers, remain divided over whether the dynamics of inflation are reasonably well explained by a link to past and anticipated future inflation together with the degree of economic slack (e.g., see Mavroeidis, Plagborg-Møller and Stock 2014). Indeed, the factors believed to drive inflation have also waxed and waned over the years with exchange rates, changes in liquidity, the choice of policy regimes and, more recently, economic slack or weak wage growth among the principal candidates used to explain low inflation and, by implication, expectations that inflation will continue to remain low.

A common feature in much of the extant empirical work that attempts to capture the role of expectations is the reliance on point forecasts such as ones published by professional forecasters, 
collected from households or firm surveys, public institutions or agencies and, more recently, by central banks. Typically, however, studies continue to rely on forecasts from a single source or emphasize the importance of point forecasts. This can be useful when attempting to understand the forecasting process as in Capistrán and Timmermann (2008).

However, unless the policy makers consider forecasts from a wide variety of sources, a more representative interpretation of dispersion about the outlook for inflation may well be ignored. Put differently, a focus on point forecasts can mislead the public into believing that there is greater consensus about future inflation than is actually the case. Indeed, a variety of explanations have been proposed to explain the formation of expectations. These range from Mankiw and Reis’ (2002) sticky information hypothesis, wherein information about macroeconomic fundamentals spreads slowly (also, see Carroll 2003) to Sims’(2015) rational inattention where agents do not always react to new information that is observed. Irrespective of the hypothesis in question forecasters will disagree about the inflation outlook. This chapter investigates the evolution of inflation forecast disagreement and, in particular, what happens when central bank forecasts serve as the benchmark. In doing so I highlight the importance of moving beyond the mere reporting of point forecasts. Additional insights about the role of monetary policy can also be obtained by looking at the dispersion of forecasts. ${ }^{1}$

Traditionally, some mean or median serves as the obvious benchmark. However, if information is indeed sticky, forecasters suffer from inattention, or the public simply relies on central bank forecasts because it is convenient to do so or in the belief that they are perhaps more likely to be accurate over time, then the benchmark against which forecast disagreement is evaluated will matter. Indeed, the possibility that the public coordinates its forecasts with those of the central bank has been used, at least in theory, to suggest that transparency need not always be beneficial 
(viz., see Morris and Shin 2002). ${ }^{2}$ Even if this outcome is unlikely to emerge in practice (Svensson 2006) an analysis of disagreement may help identify some of the differences in dispersion of private sector between households' forecasts and those of the central bank.

Given the variety of explanations for the formation of expectations the spread of inflation forecasts published by central banks ought to have considerable impact, particularly if they are credible. Moreover, paralleling the growing availability of central bank forecasts has been the rise in the availability of macroeconomic and financial data. The implication of these developments raises questions about whether forecasts should lead to more or less disagreement about the inflation outlook. Dovern (2015, p. 16), for example, claims “...it is surprising to observe high degrees of disagreement across agents when it comes to forecasting the future state of the economy.” However, it is far from clear why disagreement should not persist or even rise, given the range of theoretical explanations of expectations formation let alone different interpretations of the weight and value of different information produced by central banks. Other explanations include: substantial changes in the credibility of central banks over time (e.g., see Bordo and Siklos 2016), and varying opinions about the quality of central banks' forecasting record (e.g., IEO (Bank of England) 2015, Stockton 2012, IEO 2013, Ng and Wright 2013, Alessi et. al. 2014, just to name a few). ${ }^{3}$

This chapter considers short-term sources of inflation forecast disagreement in nine advanced economies, and takes account of the role of domestic versus global factors among other determinants. Although the focus is on the evolution of inflation forecast disagreement other contributions are also made. First, forecast disagreement should be evaluated relative to several benchmarks, and not only the mean of all available forecasts as is traditionally the case. ${ }^{4}$ Second, a set of indicators of the content of central bank announcements is considered that is inspired 
from widely used metrics in the psychology and political science literatures. The aim is to illustrate their use and potential importance as well as point out that there exists considerable scope to improve the quantification of the qualitative element of monetary policy. Third, I adapt an idea from the model confidence set approach (Hansen et.al. 2011) to obtain a quasiconfidence interval for inflation forecast disagreement. Finally, some forecasters may change their outlook as data, especially for data that are frequently revised (e.g., the output gap). Accordingly, an indicator of the impact of such revisions is also considered as a separate determinant of forecast disagreement.

The main findings can be summarized as follows. Estimates of disagreement can be highly sensitive to the chosen benchmark and central banks need not always be the benchmark of choice. The range of forecast disagreement can be high even when the level of disagreement is low. Hence, some form of uncertainty, perhaps economic policy or monetary policy uncertainty, may well represent additional factors at play. There is comparatively little evidence, other than perhaps among professional forecasters, that forecasts are strongly coordinated with those of the central bank. The evidence that central bank communication influences forecast disagreement is not strong. The quality of central bank communication may be one proximate explanation. However, there is little guidance about how to best measure the content of central bank press releases in particular. Finally, at least over the period considered, that is, one that covers the end of the Great Moderation and the GFC, there is consistent evidence that global factors impact forecast disagreement.

The rest of the chapter is organized as follows. The next section briefly considers the connection between inflation forecasts and monetary policy. Section 3 summarizes the relevant literature. Section 4 provides a working definition of forecast disagreement and describes the sources of 
data. Section 5 outlines the methodology used to investigate the determinants of inflation forecast disagreement. Section 6 describes the empirical results. The final section concludes.

\section{Forecasts and Monetary Policy}

Forecast accuracy is often established as a condition that holds on average over a particular sample period as opposed to each and every period of time. ${ }^{5}$ Yet, many forecasts, especially ones that are published by public agencies, professional forecasters, and central banks, face a trade-off between accuracy and the underpinnings of such forecasts, that is, their logical consistency and plausibility. Otherwise, forecasts risk being poorly communicated with deleterious consequences for the reputation of the forecaster (e.g., see Drehmann and Juselius 2013, Zellner 2002). It comes as no surprise then that 'judgment' almost always plays a role. This is particularly true of forecasts published by central banks. Therefore, while useful, the exclusive emphasis on forecast accuracy can be misplaced. ${ }^{6}$

Questions have also been raised about the desirability of anchoring expectations to some inflation goal (e.g., inter alia, Coibion and Gorodnichenko 2015, Bernanke 2007, Constâncio 2015, Kamada et. al. 2015, Strohsal and Winkelmann 2015). ${ }^{7}$ Therefore, investigating forecast disagreement ought also to provide some insights into forecasters' sensitivity to short-term shocks. For example, whereas central banks might 'look through' the effects of one-off supply or uncertainty shocks (e.g., oil prices or economic policy uncertainty) households and even professional forecasters might not (e.g., Lahiri et.al. 2015, Reifschneider and Tulip 2007, Boero et.al. 2015, Glas and Hartmann 2015). Once again one is led to examining forecast disagreement for additional clues. 
Admittedly, a difficulty here is that the horizon over which these expectations apply plays an important role. Monetary policy still acts with long and variable lags. Although central bankers tend to think that current policy decisions can take up to two years to take full effect some view the appropriate horizon to be much longer. ${ }^{8}$ I return to this issue below as data limitations hamper our ability to estimate measures of forecast disagreement beyond the short-term especially when cross-country comparisons are made.

The role and importance of forecast disagreement is also underscored by the fact that it is one of the components in an indicator of economic policy uncertainty (e.g., see Baker et. al. 2016). ${ }^{9}$ Nevertheless, because the scope of economic policy uncertainty is vast, lately there has been an attempt to narrow the focus to monetary policy alone (Husted et. al 2016). Sources of disagreement over the outlook stems from different weights forecasters might apply to global versus domestic shocks. This has led some research to place relatively greater emphasis on global over other determinants (inter alia, see Borio and Filardo 2007, Ciccarelli and Mojon 2010).

While realized inflation across many parts of the world may look similar, leading in some cases to deceptively similar point inflation forecasts (see, however, below), in reality, differences in the stance of monetary policy, owing in no small part to the spread of unconventional monetary policy, are arguably much larger (e.g., Carney 2015). Divergences in the effective stance of monetary policy could become more apparent from an analysis of forecast disagreement over time.

Since 2008 in the United States, and later in several other advanced economies, the dramatic fall in central bank policy rates has also meant that the outlook is incompletely communicated via 
only forecasts. Instead, there has been increased emphasis and importance placed on what central bankers say (or write; see Blinder et. al. 2008). Unlike point forecasts or the 'fan charts' that have become the staple of many central bank monetary policy reports there is greater room for interpretation about the meaning and intent of central banks statements that accompany their decisions and deliberations. As a result, there may be scope for disagreement in the inflation outlook to be influenced by communication from the monetary authority when there is little prospect for change in the policy rate or in the central bank's estimate of the future outlook for inflation.

\section{Related Literature on Forecast Disagreement ${ }^{10}$}

As noted in the introduction, forecast disagreement can be traced in part to different beliefs about how agents process information and the incentives to revise their expectations in light of new information. At least two rather different theoretical views on the subject are the sticky information and rational inattention interpretations of expectations formation. Andrade and Le Bihan (2013), for example, reject the rational inattention hypothesis but also find some difficulty with the sticky information model. ${ }^{11}$ In addition, a hybrid model that combines various hypotheses of expectations formation also fails to fit the data well. Clearly, there continues to be scope for improving our understanding of what drives inflation expectations in particular. Nevertheless, it is also clear that the lack of theoretical consensus is also reflected in how forecast disagreement is measured (also see Mokinsky et. al. (2015) for a recent survey). Glas and Hartmann (2015) consider the tension between forecast disagreement and uncertainty and rely on data from the Survey of Professional Forecasters (SPF) conducted by the European Central Bank (ECB) to show that rising inflation uncertainty typically precedes a deterioration of 
forecasting performance while disagreement is primarily determined by the state of the macroeconomy. Bachmann et. al. (2013) also report, based on the German Ifo ${ }^{12}$ Survey of Business Climate, that forecast errors are correlated with forecast dispersion and, unlike some studies to be cited below, conclude that uncertainty and disagreement may be treated as proxies for each other. More recently, there is a shift in emphasis to consider the behavior of inflation forecast obtained from household surveys and qualitative forecasts more generally (e.g., see Maag 2009, Dräger and Lamla 2016).

At a theoretical level the link between uncertainty and disagreement has also attracted considerable interest. ${ }^{13}$ Lahiri et. al. (2015) make the case that uncertainty represents one element of disagreement but it is not the only one. They then develop what they refer to as theoretically sound measures of disagreement and uncertainty but assume that forecast errors are stationary. The empirical evidence is far from reaching a consensus on the time series properties of forecast errors. ${ }^{14}$ Nevertheless, the authors are correct in pointing out that there exists a common component across forecasts or forecast errors. Data availability and data structure also play a role in the ability to separately measure forecast uncertainty and disagreement as argued in Boero et. al. (2015). ${ }^{15}$ They conclude, using data from the Bank of England’s Survey of External Forecasters, that forecast disagreement can be useful to proxy uncertainty but only when these measures disagreement exhibits large changes. Clements and Galvão (2014) propose a distinction between ex ante and ex post measures of uncertainty, the latter being determined by realized data while former is determined by models or probabilistic considerations, and conclude, for example, that ex ante tracks well ex post uncertainty when the forecast horizon is short.

Jurado et. al. (2015) also consider the dispersion versus uncertainty concepts with the objective of empirically identifying, for the U.S., salient uncertainty 'events'. As far as the sample covered 
by the present study is concerned the most important such event is the Global Financial Crisis (GFC) of 2007-9. Nevertheless, they also find that uncertainty rises in recessions as well as when the forecast horizon lengthens. The authors interpret uncertainty as the common latent factor among individual measures of uncertainty.

Surveying empirical studies that examine varieties of forecasts it is still the case that research tends to rely primarily on U.S. data. This is not surprising given the number of published forecasts and the span of available data that can be brought to bear on the problem being investigated (also see below). Typically, investigators will resort to SPF, or forecasts published by the Federal Reserve (i.e., Greenbook or Federal Open Market Committee (FOMC)), and occasionally Blue Chip or a survey (e.g., University of Michigan Survey).

While accuracy and efficiency of forecasts continue to be the focus of some studies (e.g., Chang and Hanson 2015, IEO 2013) attention has turned in recent years to asking whether the data are also informative about the forecaster's knowledge about how monetary policy functions and whether their forecasts are consistent with core economic relations (e.g., a Taylor rule, a New Keynesian Phillips curve). Studies in this vein include Carvalho and Nechio (2014) who report that households' expectations are consistent with a simple Taylor rule type specification but not some of the other macroeconomic relations they examine. Dräger (2015) considers the case of Swedish households while Dräger et. al. (2015) explore a range of U.S.-based forecasts and find that households' forecasts are less consistent with theoretical propositions from macroeconomics than ones produced by professional forecasters. Kamada et. al. (2015), relying on Japanese data, report that expectations differ according to whether the household is or is not well-informed, based on an Opinion Survey conducted by the Bank of Japan. 
Dovern (2015) attempts to go beyond a uni-dimensional analysis of forecast disagreement by proposing a multivariate version. However, his analysis is restricted to the Survey of Professional Forecasters and Consensus forecasts. Moreover, the multivariate measure assumes that forecasters effectively use the same model. Finally, it is unclear whether a multivariate indicator of this kind actually provides new insights about the evolution of forecast disagreement over time, at least compared to existing estimates (e.g., see Siklos 2013).

Other themes that have attracted attention recently include the role that news plays in influencing expectations. Bauer (2015), for example, uses the Blue Chip and SPF forecasts to estimate their sensitivity to macroeconomic news and concludes that a policy of targeting inflation contributes to reducing the volatility of inflation expectations and, therefore, represents an effective anchoring device. ${ }^{16}$ Anchoring of inflation expectations among households in Japan is the focus of the studies by Kamada et. al. (2015), and Nishiguchi et. al. (2014). These studies report that central bank announcements (e.g., the introduction of quantitative and qualitative easing or QQE) can shift the distribution of expectations towards the announced objective. ${ }^{17}$ Central bank communication also figures prominently in Dräger et. al. (2015). They rely on this signal as a device to ascertain how households versus professionals respond to such signals. The authors conclude that while households' expectations formation processes are generally less consistent with macroeconomic theory than those employed by professional forecasters efforts by central banks to become more transparent have narrowed the gap between forecasters. Strohsal et. al. (2015), and Strohsal and Winkelmann (2015), also consider the anchoring issue and the role of news effects and reach the strong conclusion, in the U.S. case, that inflation was almost "perfectly" anchored since 2004. Other than in 2008 the central banks investigated ${ }^{18}$ were able to control inflation expectations. 
Coibion and Gorodnichenko (2015) argue that the anchoring of expectations is a double-edged sword since a sharp change in, say, commodity prices (e.g., oil) ought to lead to a revision of expectations, even if only for a short time, otherwise the risk of deflation in an already low inflation environment would be much greater. Hence, the U.S. economy, where the 2008-2009 financial crisis originated, may well have benefited from the absence of perfect expectations anchoring among households. ${ }^{19}$ Nevertheless, it is also possible that this conclusion holds only for U.S. data only as the evidence for Japan in Nishiguchi et. al. (2014) and Eurozone data reported in Bachmann et. al. (2013) would seem to contradict the claim made by Coibion and Gorodnichenko (2015).

The anchoring of inflation expectations is also relevant for monetary policy more generally especially since an increasing number of central banks drove their policy rates near to, or reached, the zero or effective lower bound (ZLB or ELB), ${ }^{20}$ as well as introducing additional monetary policy loosening measures generally referred to as quantitative easing (QE). In particular, the current constellation of global economic slack and persistently low inflation ${ }^{21}$ would seem to offer the opportunity for monetary policy to become "irresponsible" by permitting observed and expectations of inflation to rise so that they are safely away from deflation (e.g., see Woodford 2012). Others counter that a central bank’s reputation is at stake and, consequently, an un-anchoring of expectations might result (e.g., Koo 2009). As noted above the goal of anchoring inflation expectations is possibly the most cherished one among central bankers next to the maintenance of financial stability especially following the events since 2007 . It is important to stress, as noted in the introduction, there is no consensus on the horizon over which expectations ought to be anchored. 
What about the influence central bank forecasts on the forecasts of others? As noted above, the theoretical predictions of Morris and Shin (2002) are difficult to test directly and, in any case, have been criticized by others as unrealistic (e.g., Svensson 2006). The literature that investigates the performance of central bank forecasts is generally restricted to the U.S. experience for reasons already stated though studies referred to earlier for the U.K., Sweden, and the Eurozone, notably, are now also available. Other than Siklos (2013) only Hubert (2015) provides recent evidence for Sweden, U.K., Canada, Japan and Switzerland. ${ }^{22}$

4. Measuring Forecast Disagreement, Uncertainty, and Data

As noted above there is no universally agreed upon measure of inflation forecast disagreement. Inflation is defined here are the annual rate of change in a consumer price index (CPI) as this is the purchasing power indicator for which forecasts are most frequently published. ${ }^{23}$ The results reported below consider the squared deviations measure. ${ }^{24}$ Let $d_{t h}^{j}$ represent forecast disagreement at time $t$, over a forecast of horizon $h$, for economy $j$. Then,

$$
\mathrm{d}_{\text {th }}^{\mathrm{j}}=\frac{1}{\mathrm{~N}_{\mathrm{j}}-1} \sum_{\mathrm{i}=1}^{\mathrm{N}_{\mathrm{j}}}\left(\mathrm{F}_{\mathrm{ith}}^{\mathrm{j}}-\overline{\mathrm{F}}_{\mathrm{gth}}^{\mathrm{j}}\right)^{2}
$$

where $F$ is the inflation forecast, $N_{\mathrm{j}}$ is the number of forecasts, $i$ identifies the forecast, while $\bar{F}^{j}$ represents the mean forecast value across forecasting groups $g$ (to be defined in greater detail below) in economy $j$. Equation (1) is a measure of forecast dispersion. The absolute standard deviation of $d_{\text {th }}^{j}$ is then normalized to produce values that range between 0 and 1 . Accordingly, the following expression is reported below 


$$
\tilde{\mathrm{d}}_{\mathrm{th}}^{\mathrm{j}}=\left|\sqrt{\frac{1}{\mathrm{~N}_{\mathrm{j}}-1} \sum_{\mathrm{i}=1}^{\mathrm{N}_{\mathrm{j}}}\left(\mathrm{F}_{\mathrm{ith}}^{\mathrm{j}}-\overline{\mathrm{F}}_{\mathrm{gth}}^{\mathrm{j}}\right)^{2}}\right|
$$

suitably normalized. ${ }^{25}$ Cross-economy comparisons are then more easily made.

Forecasts can be grouped in a variety of ways to generate forecast combinations. These include ones prepared by central banks (CB), forecasts conducted among households and businesses (S), a set of forecasts (P) by public agencies (i.e., OECD, IMF, Consensus), as well as a group consisting of professional (PR) forecasts (e.g., Consensus, Survey of Professional Forecasters). Mean values of $d$ are then calculated for each economy $j$ in the dataset. Grouping forecasts is likely to be useful for a variety of reasons. For example, some of the data used in this study are projections, others are actual forecasts. Moreover, the assumptions and models (whether of the implicit or explicit variety) used to generate inflation forecasts are also likely to differ across the available sources. Not to be forgotten is the considerable evidence that favors simple forecast combinations over other forms of aggregation of forecast or even forecasts by specific forecasters (e.g., see Timmermann 2006). Of particular interest in this study is the case where the benchmark are forecasts published by the central bank, that is, $\overline{\mathrm{F}}_{\mathrm{CBth}}^{\mathrm{j}}$.

The potential connection between disagreement and uncertainty was raised earlier. Lahiri et. al. (2015; also see references therein) outline the requirements under which measures of disagreement can underestimate forecast uncertainty or, rather, the conditions under which the two move in parallel with each other. Boero et. al. (2015) cover much the same ground and report that forecast disagreement and uncertainty are reasonable proxies for each other especially when the former exhibits large and frequent changes. Among the difficulties researcher encounter when attempting to disentangle the two concepts is that most forecasts are aggregated. 
Even forecasts that have a probabilistic element can be classified into arbitrary bins. Hence, the precise information needed to measure a 'pure' form of uncertainty is unobserved. For these reasons the present study focuses on disagreement as proxied by a measure of dispersion around different candidates for some central tendency. ${ }^{26}$

The sampling frequency of the raw data ranges from the monthly to semi-annual forecasts. The focus is on the short-term inflation outlook, namely the one year ahead horizon although the precise horizon can be a little longer depending on the data source (see below). Hence, $h$ in equation (2) is set to 1 . Moreover, forecasts are either of the fixed event (i.e., a forecast for inflation for a particular calendar year) or fixed horizon (e.g., one quarter or one year ahead) variety. Hence, many of the forecasts used below end up covering a period of up to two calendar years. Since most monetary policy actions are believed to take about two years to influence economic activity, including inflation, the time horizon is appropriate for an analysis of forecast disagreement.

Fixed event data are converted into a fixed horizon using a simple procedure. ${ }^{27}$ All raw data, however, were converted to the quarterly frequency to facilitate estimation of the macroeconomic determinants of (2). Data at the monthly or semi-annual frequencies are converted to quarterly data via quadratic-match averaging. ${ }^{28}$ Finally, survey data need to be converted from index form into an inflation rate. Two approaches are often employed, namely the regression and probability methods. The former is associated with the work of Pesaran (1985, 1987) while the latter is best known from the work of Carlson and Parkin (1975). Both techniques are used and the mean of the two resulting series serve as the proxy for inflation expectations or forecasts from the relevant households and firms data (see also Siklos 2013). 
Ideally, I would also have liked to collect data on medium-term to long-term inflation forecasts for all of the nine economies considered here. However, other than Consensus forecasts and some forecasts from the Survey of Professional Forecasts it proved to be impossible to obtain a complete, let alone a comparable, set of forecasts 5 to 10 years out for all of the forecasting groups analyzed here.

Nine economies are examined, five of which explicitly target inflation. The inflation targeting (IT) group of countries are Australia (RBA), Canada (BoC), New Zealand (RBNZ), Sweden (SR or Riksbank), and the U.K. (BoE). The remaining economies are not considered to have adopted inflation targeting though all of them aim for price stability and have even indicated a numerical objective they aim to meet as a means of guiding inflationary expectations: the euro area (ECB), Japan (BoJ), Switzerland (SNB), and the U.S.A. (Fed). ${ }^{29}$ The full sample, before any data transformations are applied, is 1999Q1 to 2014Q4. ${ }^{30}$

Macroeconomic and financial time series were obtained from International Financial Statistics CD-ROM (June through August 2015 editions), the BIS, OECD release data and revisions database (http://stats.oecd.org/mei/default.asp?rev=1) and the databases of the individual central banks. They include: an output gap, both domestic and global, obtained by applying an H-P filter to the log of real GDP, ${ }^{31}$ the price gap, namely the difference between observed and core inflation rates, ${ }^{32}$ and an indicator of commodity price inflation (i.e., inflation in oil prices; Brent crude price per barrel). Finally, to capture the possible effects of uncertainty the VIX is added. ${ }^{33}$ Table 1 updates details about the number and types of forecasts that were also the basis of the results in Siklos (2013). A total of 83 forecasts from a variety of sources are used. The majority of them (43) are from professionals or various international institutions such as the IMF (i.e., the 
World Economic Outlook (WEO)), and the OECD. Professional forecasts include the mean forecast from Consensus Economics, forecasts collected from The Economist, as well as the US and euro area Surveys of Professional Forecasters (SPF). All 9 central banks in the data set publish inflation forecasts. ${ }^{34}$ Over a third of the forecasts (27) are obtained from households and firm surveys.

Short-term forecasts are important since they can signal the emergence of some underlying shift in the credibility of monetary policy. Blinder et.al. (2008) point out that "short-run" communication, such as the release of an inflation forecast, is likely to have a wide variety of effects and this could be revealed in the behavior of forecast disagreement. Moreover, short-term forecasts are precisely those that are likely to be the focus of transparent central banks. Finally, since the paper aims to determine the sensitivity of expectations to central banks announcements a focus on the one year horizon is warranted.

When central banks loosened monetary policy in response to the Great Recession verbal forms of communication became increasingly important as a means of signaling the stance of monetary policy. This is also highlighted by the fact that, even if the stance of monetary policy has changed, policy rates in many advanced economies hardly changed at all. At the same time, language was carefully crafted to signal policy easing in the foreseeable future or at least until there are clear signs that the state of the economy improves and, with it, risks for inflation exceeding its objective. ${ }^{35}$ In such an environment the distinction between positive and negative news announcement is germane to a study of forecast disagreement. Of course, incorporating the narrative element of monetary policy is not new (e.g., see Romer and Romer 1989, 2004) but the manner in which these effects are incorporated does differ across studies (e.g., see Lonbardi et. al. 2017). 
We evaluate the content of monetary policy announcements by developing a proxy for the tone of central bank communication. I evaluate the conduct of monetary policy by generating a vector of variables that quantifies the content of the language used in central bank press releases. Typically, researchers have attempted to interpret whether the monetary authority aims to tighten or loosen policy based on a reading and subsequent assessment of the bias in central bank announcements turning these evaluations typically into binary dummy variables. Instead, I use the DICTION 6.0 algorithm (see Hart, Childers, and Lind 2013) to quantify the tone of communication emanating from central banks. ${ }^{36}$ Alternatively, DICTION can be viewed as an algorithm that collects ideas that are expressed in a document. Next, I compute an idea density indicator of the number of ideas per, say, 10 words. ${ }^{37}$ To remain consistent with the relevant literature on central bank communication I refer to the idea density measure as an indicator of the content of central bank communication.

The DICTION algorithm transforms a collection of words (i.e., 'bags of words') into a numerical indicator the content or tenor of the document. This relies on a dictionary of words that convey meaning along various dimensions. There is no unique way of doing so and, indeed, the selection of words used to create such indicators can be crucial (e.g., Loughran and McDonald 2016). Indeed, there exst a large number of algorithms all claiming to accurately quantify the content of documents. Assuming that consumers of inflation forecasts are varied, from the general public to the specialist, it is likely that the words used, especially by central banks, will be a mix of everyday and more specialized words.

Expressions and terms are grouped into two categories: positive and negative. ${ }^{38}$ A positive tone signals current and anticipated improvements in economic conditions and this is also interpreted as signaling higher future inflation. In contrast, a negative tone implies a weakening of economic 
conditions and this is viewed as being conducive to the central bank expecting lower future inflation. The numerical value associated with the tone of central bank announcements (i.e., press releases and minutes if these are published) is based on the press release that accompanies central bank announcements of the policy rate setting. DICTION calculates the relative frequency with which words used in central bank communication are consistent with the chosen categories that are associated with either positive or negative sentiment about overall economic conditions. The words are drawn from a dictionary of over 10,000 words.

There is always a subjective element in the measurement of the content of any document and central bank press releases and committee minutes, where available, are no exception. However, evaluating the tone of central bank announcements is likely made easier since central bankers are well-known to carefully weigh the usage or removal of specific terms. ${ }^{39}$

\section{Econometric Specification}

Once forecast disagreement is estimated it is natural to ask what kind of economic phenomena can explain its evolution over time. It is hypothesized that forecast disagreement can be explained by a few common determinants. Some are domestic while others are considered global. In addition, it is conceivable that the level of forecast disagreement is influenced by the level of inflation or its forecasted value. The simplest way to proxy this is by relying on a mean forecast, either across forecast sources or across economies. I consider both the mean inflation forecast across the various available sources as well as an estimate that extracts the first principal component of these same forecasts. The same approaches are used to generate a common global factor based on forecasts across countries. 
Accordingly, the specification used to estimate the determinants of inflation forecast disagreement is written as follows:

$$
\tilde{\mathrm{d}}_{\mathrm{t}+\mathrm{h} \mid \mathrm{t}}^{\mathrm{j}}=\alpha^{\mathrm{j}}+\beta_{0} \Gamma_{\mathrm{t}}^{\mathrm{j}, \mathrm{D}}+\beta_{1} \Gamma_{\mathrm{t}}^{\mathrm{j}, \mathrm{G}}+\eta_{\mathrm{t}+\mathrm{h} \mid \mathrm{t}}^{\mathrm{j}}
$$

where $\tilde{d}$ is defined above (see equation (1)) and inflation forecast disagreement, $\Gamma^{\mathrm{D}}, \Gamma^{G}$ are, respectively, the vectors of domestic (D) and global (G) determinants affecting inflation forecast disagreement. ${ }^{40}$ The subscript $t+h \mid t$ indicates that disagreement is based on the horizon $t+\mathrm{h}$, where $h=1$, that is, for a fixed horizon period of one year ahead conditional on information at time $t$. Note also that since a global component is included for each $j$ forecast disagreement in each economy is a function of both domestic and international determinants. As noted above domestic factors include variables likely to impact not only forecasts but forecast disagreement, including an indicator of uncertainty (here the VIX), oil prices, and a measure of the qualitative content of central bank press releases announcing the stance of monetary policy, as measured by their tone.

When the domestic or global common factors are estimated via the mean or principal components with factor loadings that are constant, ${ }^{41}$ the common factor is obtained from the following estimated relationship

$\Gamma_{\mathrm{t}}^{\mathrm{j}, \mathrm{k}}=\mathrm{p}_{\mathrm{t}}^{\mathrm{j}, \mathrm{k}} \mathbf{v}_{\mathrm{t}}^{\mathrm{j}, \mathrm{k}}+\mathrm{e}_{\mathrm{t}}^{\mathrm{j}, \mathrm{k}}$

where $\Gamma$ has been defined, $k=\mathrm{D}, \mathrm{G}$, and $\mathrm{p}_{\mathrm{t}}^{\mathrm{j}, \mathrm{k}}$ represent the factor loadings based on the time series vector $\mathbf{v}$ and $e_{t}^{j, k}$ is a residual term.

6. Empirical Results 
Figure 1 and Figure 2 show CPI headline inflation rates as well as two estimates of one yearahead forecasts of inflation. In Figure 1 inflation forecasts are proxied by the overall mean of all available forecasts for each one of the 9 economies in the study (see Table 1). In Figure 2 the proxy for one year ahead inflation rates shown is the first principal component of inflation forecasts. Generally, estimates reveal that a single factor explains over $70 \%$ of the variation in inflation forecasts (results not shown). However, for Australia, the U.K., Sweden and the U.S. either two or three factors were estimated although the additional factors explain less than $20 \%$ of the variation in available forecasts. Moreover, in all 9 economies, the factor loadings for the first principal component are all positive. Due to the unbalanced nature of the dataset for inflation forecasts for the sake of comparison the sample shown in both figures is from 2002 on although forecasts begins in 1999.

Both sets of forecasts respond to observed inflation although the factor model generated estimates follow observed inflation somewhat more closely. More often than not, inflation forecasts also move contemporaneously with headline inflation rates. However, there are a few instances, most notably around the GFC of 2008-2009, when forecasts lag behind inflation for a short period of time. Finally, there is little visual evidence that forecasts deviate persistently from observed inflation. Of course, by combining a wide range of forecasts I am exploiting the wellknown benefits from combining forecasts. Since there is a longer sample when mean inflation forecasts are used the econometric evidence presented below relies on mean inflation forecasts for the common factor. The conclusions reached below are unaffected when the principal components proxy is employed.

Relying on the small sample correction for the widely used Diebold-Mariano (1995) test I am unable to reject the null that central bank forecasts are the same as the other forecast 
combinations considered for Australia, Japan, New Zealand, and Sweden. For Canada and the Eurozone the only rejections are obtained vis-à-vis households and firms forecasts with central bank forecasts proving to be the superior forecast. In the case of Switzerland, the U.K. and the U.S., there are frequent rejections with the exception of public forecasts for the U.K., and households and firms forecasts for the U.S. In the case where the null is rejected central bank forecasts are deemed superior to the rest (results not shown). Hence, it is far from universally the case that reliance on central bank forecasts, based on their average accuracy, is the preferred choice.

Figure 3 plots the cumulative revisions in the growth rate of the output gap. As noted above, output data are frequently revised and may well have an impact on forecast disagreement. Each quarterly vintage is revised every quarter. I constructed an output gap, using the H-P filter with a smoothing parameter of 100,000, and then calculated the growth rate on an annualized basis. The change in the output gap over time is then due to revisions in the data which are summed over time.

It is immediately observed from Figure 3 that in most economies revisions are positive pre-GFC. This means that temporal revisions to the output gap suggest that they are becoming larger over time. In contrast, revisions turn negative post-GFC and may well be one reason why unconventional monetary policies (i.e., quantitative easing) were introduced. After some time revisions begin to rise once again in most cases (Australia, Japan, and the Eurozone are two exceptions) beginning around 2012. It is conceivable then that (some) forecasters may revise their forecasts based on this kind of new information leading to changes in forecast disagreement. 
Figures 4 and 5 provide graphical evidence of the evolution of inflation forecast disagreement based on two different aggregations of the dataset. Figure 4 provides an estimate of the mean of $\tilde{\mathrm{d}}$ (see equation (2)) for each one of the 9 economies in the sample. Moreover, a quasiconfidence interval is also provided by estimating the range of estimates of forecast disagreement. Recall that there is no a priori reason to believe that the only benchmark is the overall mean inflation forecast, the traditional choice in these exercises. Since in most cases we do not observe the model(s) used by the individuals or groups that provide inflation forecasts but all forecasters acknowledge that the forecasts or others, together with some judgement influence how their expectations are formed, a total of 6 separate versions of inflation forecast disagreement were estimated. The resulting quasi-confidence interval is akin to the model confidence set approach but, in the present case, without explicit knowledge of the range of model specifications.

The evidence suggests considerable variation in inflation forecast disagreement across economies and over time. Indeed, in most cases, there tend to be brief periods of sharply higher levels of disagreement followed, typically, by longer periods of low disagreement. Greater disagreement over the inflation outlook is clearly visible in almost every economy around the time of the GFC. However, there are other periods of higher forecast disagreement not directly associated with a financial crisis. For example, in the U.S., there is rising disagreement in the period leading up to the tech bubble of 2001 and again during the phase when the Federal Reserve gradually tightens monetary policy until 2005. Similarly, the sharp fall in disagreement after the GFC is reversed during the period when quantitative easing policies are introduced by the Fed (i.e., QE2) in 2010. In Japan, forecast disagreement actually exceeds levels reached during the GFC when the Governor Kuroda launches QQE in 2013. Notice too that there is rising 
inflation forecast disagreement in the early 2000s over the period when the BOJ is in the midst of QE1. Other illustrations of the impact of monetary policy decisions on forecast disagreement include the Swiss National Bank’s decision to target the Swiss Franc's exchange rate in 2011 and the Reserve Bank of Australia's change of course in setting of its policy rate (the cash rate) beginning in November 2011. Clearly, no matter how appropriate these unconventional policies are, there are obvious limits in central banks' ability to manage their impact on forecast disagreement. Whether better communication would have moderated some of these effects is, as yet, unclear (see below).

It is also worthwhile remarking on the behavior of the quasi-confidence intervals. These tend to be wider the higher is the level of forecast disagreement. Nevertheless, it is interesting to observe that in the U.S. there is the appearance of a narrow range about the short-term inflation outlook at the height of the GFC. This is not the case in the other economies considered. In other words, forecasters were in accord about the high level of disagreement about the inflation outlook. Similar to the point estimates, the quasi-confidence intervals can grow wider or narrower very quickly. Whether the bands shown can be likened to an estimate of forecast uncertainty is unclear. Nevertheless, it should be pointed out that low levels of disagreement need not imply narrow quasi-confidence bands as the examples of New Zealand, Australia, Canada, and Sweden demonstrate. It is interesting that, for the Eurozone, the results are similar but not the same as in López-Pérez (2014) who studies uncertainty in the ECB’s SPF. The quasi-confidence intervals in Figure 4 reveal that uncertainty rises as early as 2000, not 2001, but does decline in 2004. I also find a rise in 2005 and 2006 not reported in the same study. Thereafter, the results mirror ones reported in López-Pérez (2014). 
Figure 5 plots forecast disagreement on a global scale. Instead of the quasi-confidence bands the point estimates for 4 different benchmarks, namely central banks, professional forecasters, forecasts of public agencies, and households and firms forecasts are shown alongside the conventional approach of using the mean of all forecasts as the benchmark. The term global is used here because inflation forecasts across all 9 economies are averaged (a similar result is obtained when the first principal component is used as the global inflation forecast proxy). The motivation, as discussed earlier, is the view that inflation has increasingly been overtaken in recent years by a global dimension.

It is clear that the selection of the benchmark has a considerable impact on forecast disagreement. Conventional calculations of forecast disagreement come closest to ones generated based on professional forecasts while the least coherent benchmark is the one based on central bank forecasts. Households, firms and public forecasts represent intermediate cases. Like their domestic counterpart (see Figure 4) all show a rise in forecast disagreement around the time of the GFC but whereas overall forecast disagreement fell sharply since then forecast disagreement relative to the central banks benchmark remains elevated. Estimates of forecast disagreement also demonstrate a common response to the events of the early 2000s, when the tech bubble burst and concerns were expressed then about the potential for deflation spreading outside Japan.

Tables 2 and 3 present estimates based on equation (3). Both ask the extent to which we can find a few common determinants that drive inflation forecast disagreement as a function of different benchmarks. To economize on space three benchmarks are chosen. They are: all forecasts excluding ones from the central bank, central bank forecasts, and household and firms forecasts. It is difficult to find common determinants of disagreement but this is not surprising if different forecasts are thought to be driven by different information sets. Nevertheless, differentials 
between domestic and global output gaps, the gap between headline and core inflation, and average forecasts of inflation relative to a global mean forecast of inflation, come closest to what could be termed common driving factors of inflation forecast disagreement. ${ }^{42}$

It is interesting to note that gaps in headline versus core inflation have relatively small effects on forecast disagreement. The only consistent exceptions are Australia and the Eurozone where the gaps raises disagreement in the former but reduces it in the latter. Central banks, of course, are fond of stressing that even if the control of headline inflation is their mandate operationally core inflation is more relevant, especially in the short-run. The reason is that changes in core inflation allow the monetary authority to look past temporary supply side factors that need not be reflected in inflation expectations. Nevertheless, there is no reason, a priori, for forecasters to react in the same fashion across different economies. Indeed, as shown for example in Table 2, forecast disagreement is consistently affected by the inflation gap (PGAP) in only two economies. There is only a smattering of reaction to this variable in a few other economies. These results could conceivably also reflect the relative success of some central banks at communicating threats to meeting their operational inflation objective.

A rise in domestic output relative to global economic conditions raises forecast disagreement except in the U.S. where it has the opposite effect unless the benchmark is a central bank forecast. Turning to the global variables oil price inflation has effectively no impact on forecast disagreement other than a modest reduction in Canada when households and firms forecasts serve as the benchmark. The failure of oil prices to significantly impact disagreement is not surprising since forecasters, including households and firms, typically view these prices as having a fairly immediate but possibly short-run impact on inflation. Of course, forecasters may 
still disagree about the pass-through effects although these should emerge via the uncertainty around the point estimates of forecast disagreement.

The VIX, a commonly used indicator of stock market volatility is also sometimes interpreted as a measure of uncertainty, ${ }^{43}$ has a statistically significant impact on disagreement in relatively few cases but the effect appears to be economically small. If the VIX is a proxy for uncertainty then the estimates of disagreement appear to be very nearly of the pure variety. ${ }^{44}$ Of course, the addition of real time revisions may also represent another form of uncertainty that can influence inflation forecasts. Interestingly, cumulative real time revisions tend to consistently reduce forecast in the Eurozone, the U.K., and Japan. In contrast, these same revisions raise disagreement in the U.S. where, arguably, these types of observations are more readily available. Nevertheless, in several of the oldest inflation targeting economies (i.e., Australia, Canada, Sweden and, to a slightly lesser extent New Zealand), forecast disagreement is not seen as being affected by data revisions. This could reflect the anchoring of inflation expectations although the evidence here is only suggestive.

Forecast disagreement also tends to rise when the domestic inflation outlook is higher than average global inflation forecasts. To the extent that central banks are concerned about sources of the un-anchoring of inflation expectations, the gap between domestic and global inflation forecasts nay represent one such source.

Finally, central bank communication has little influence on forecast disagreement with the exception of the U.K where it does serve to reduce disagreement. In contrast, RBNZ communication is seen to increase forecast disagreement in New Zealand. If more was expected from central bank communication then the results could perhaps also be explained by the 
sampling frequency or the manner in which the content of central bank announcements is proxied. The last point is an important one and the results presented here at least serve as a reminder that evaluating the content of central bank communication is fraught with difficulty. In any event, the objective is to highlight that communication can matter. Future research will determine more carefully what role this plays in explaining forecasts and forecast disagreement. ${ }^{45}$ It may also be the case that central bank communication can influence inflation expectations but not the extent to which different forecasters see the short-term inflation outlook. ${ }^{46}$ One could interpret the result that central bank communication does not increase forecast disagreement as a communications success.

In Table 3 the mean of various proxies of disagreement, and the maximum or minimum levels of disagreement (see Figure 4) are instead regressed against the same determinants used to generate the results shown in Table 2. In general it appears that the same variables broadly drive the entire distribution of estimates of inflation forecast disagreement. Therefore, to the extent that the quasi-confidence intervals shown are informative about uncertainty over the inflation outlook differences of opinion do not appear to stem from a shift of focus to different determinants, at least among the ones considered here.

Finally, Figure 6 serves as another reminder that findings about short-term inflation forecast disagreement can be highly sensitive to the benchmark used to generate estimates of $\tilde{d}$ as well as illustrating that, in spite of a global component to inflation, disagreement can differ substantially across countries. To illustrate, I begin with a reminder that, based on estimates shown in Figure 4, it may be useful to characterize inflation forecast disagreement as operating in two states, namely a high or a low disagreement state. Hence, it seems appropriate to estimate a Markovswitching model where, in most cases, disagreement is determined by a constant and a regime 
dependent AR(1) term. The resulting smoothed probabilities of being in a high disagreement state are plotted in Figure 6 for the same three cases reported in Table 2. ${ }^{47}$

Three results are apparent from these figures. First, when the benchmark relies on the central bank’s forecast, professional forecasts can yield similar estimates of being in the high disagreement state. However, there are at least two notable exceptions. Inflation forecast disagreement remains in the high state for the U.S. while a central bank benchmark gives the impression that forecasters are in the low disagreement state. Japan's experience is essentially the reverse.

Second, it is also clear that disagreement vis-à-vis the central bank or vis-à-vis households and firms forecasts can yield sharply different interpretations about the likelihood of being in a high disagreement state. Lastly, even if there is a significant global element driving inflation forecast disagreement, largely driven by common shocks (e.g., the GFC), the domestic component remains important and all three figures suggest that divergences in views across the economies examined persist, whether economies are in crisis conditions or not.

\section{Conclusions and Implications}

This chapter has examined the evolution of disagreement over the short-term inflation outlook in nine advanced economies during the decade and half beginning in the 2000s. The chapter focuses on how disagreement is largely shaped by the benchmark against which this concept is evaluated and the role of potential shocks to the inflation process such as the global financial crisis.

Overall, forecast disagreement is highly sensitive to the group of forecasters chosen as the benchmark a feature largely neglected in the relevant literature and important in view of the 
growing number of forecasts published by central banks. Several other conclusions are also drawn. The evidence also reaffirms the power of forecast combinations to deliver superior forecasts. Next, and not surprisingly, the GFC led to a spike in inflation forecast disagreement that was short-lived. Nevertheless, there were other periods when forecast disagreement rose sharply in some economies but not others. Estimation of a quasi-confidence interval for forecast disagreement finds that variation around a mean level of disagreement is high when disagreement reaches a high state. Nevertheless, the relationship is not a straightforward one as there are instances when the range of disagreement is high even when the average level of disagreement is low. If the quasi-confidence intervals represent a measure of forecast uncertainty then low and high levels of forecast disagreement can co-exist with high levels of uncertainty. While there a global component in forecast disagreement that is empirically relevant the domestic determinants appear to be of first order importance. More importantly, there appear to be relatively few indications that forecasts are coordinated with those of central banks. Also, central bank communication appears to play a relatively minor role in explaining forecast disagreement but this could be interpreted as a success for the monetary authorities. Moreover, data revisions are also found to affect forecast disagreement. Finally, it also appears that forecast disagreement can be reasonably seen as a variable that operates in two regimes, namely high and low disagreement regimes.

A number of extensions and unresolved questions remain. If central bank communication is thought, a priori, to be a separate and significant determinant of disagreement the present study may not have measured it precisely enough or the quarterly sampling frequency is too coarse to properly capture its significance. ${ }^{48}$ Alternatively, the communication variable is proxied reasonably well, certainly no worse than an output gap, but is related to levels of expected 
inflation and not disagreement over the inflation outlook. It would also be worthwhile to explore asymmetries in forecast disagreement such as whether recessions versus recoveries lead forecasters to focus on different determinants. ${ }^{49}$ Alternatively, inflations versus disinflations (and, possibly, deflations) could represent another source of asymmetry. We leave these extensions to future research. Finally, given the differences in behavior of forecast disagreement across the 9 economies examined, there is potentially scope for asking whether forecast disagreement is an indicator of the degree of perceived cross-economy divergences in monetary policy. These extensions are left for future research. 
Table 1 - Numbers of Forecasts and Forecast Types

\begin{tabular}{|c|c|c|c|}
\hline Economy & Total & Survey type & Central Bank \\
\hline AUSTRALIA & 8 & 3 & 1 \\
\hline CANADA & 7 & 1 & $1^{*}$ \\
\hline Euro area & 9 & 3 & 1 \\
\hline JAPAN & 12 & 6 & $2^{* *}$ \\
\hline NEW ZEALAND & 7 & 1 & 1 \\
\hline SWEDEN & 8 & 3 & 1 \\
\hline SWITZERLAND & 6 & 1 & 1 \\
\hline U.K. & 12 & 5 & $3^{\$}$ \\
\hline U.S.A. & 14 & 4 & $2^{@}$ \\
\hline TOTALS & 83 & 27 & 13 \\
\hline
\end{tabular}

NOTES: * Bank of Canada's baseline forecast; ${ }^{* *}$ Two versions of BoJ monetary policy committee forecast; ${ }^{\$}$ BoE unconditional and conditional forecasts as well as BoE Staff forecasts;

${ }^{\circledR}$ Greenbook and FOMC forecasts. Professional and public forecasts are the remaining forecasts.

The latter are forecasts published by government or international agencies. 
Table 2a Determinants of Forecast Disagreement: All Forecasts Excluding Central Bank Forecasts

\begin{tabular}{|c|c|c|c|c|c|c|c|c|c|}
\hline Dep. Var: & AUS & CAN & CHE & EUR & GBR & JPN & NZL & SWE & USA \\
\hline Constant & $\begin{array}{c}-0.061 \\
(0.180) \\
\end{array}$ & $\begin{array}{c}0.095 \\
(0.173) \\
\end{array}$ & $\begin{array}{c}0.160 \\
(0.170) \\
\end{array}$ & $\begin{array}{c}0.334 \\
(0.098)^{*} \\
\end{array}$ & $\begin{array}{c}0.253 \\
(0.266) \\
\end{array}$ & $\begin{array}{c}0.775 \\
(0.093)^{*}\end{array}$ & $\begin{array}{c}-0.084 \\
(0.095) \\
\end{array}$ & $\begin{array}{c}0.351 \\
(0.143)^{* *}\end{array}$ & $\begin{array}{c}-0.282 \\
(0.155) \dagger\end{array}$ \\
\hline $\begin{array}{c}\text { GAPQ- } \\
\text { GLOBALGA } \\
\mathrm{P} \\
\end{array}$ & $\begin{array}{c}0.063 \\
(0.023)^{*}\end{array}$ & $\begin{array}{c}-0.026 \\
(0.049) \\
\end{array}$ & $\begin{array}{c}0.053 \\
(0.018)^{*}\end{array}$ & $\begin{array}{c}0.161 \\
(0.041)^{*}\end{array}$ & $\begin{array}{c}0.098 \\
(0.036) *\end{array}$ & $\begin{array}{c}-0.008 \\
(0.037) \\
\end{array}$ & $\begin{array}{c}0.001 \\
(0.018)\end{array}$ & $\begin{array}{c}0.022 \\
(0.032)\end{array}$ & $\begin{array}{c}-0.094 \\
(0.037)^{*}\end{array}$ \\
\hline PGAP & $\begin{array}{c}0.181 \\
(0.056) *\end{array}$ & $\begin{array}{c}-0.042 \\
(0.032) \\
\end{array}$ & $\begin{array}{c}-0.113 \\
(0.091) \\
\end{array}$ & $\begin{array}{c}-0.124 \\
(0.035)^{*}\end{array}$ & $\begin{array}{c}0.009 \\
(0.052)\end{array}$ & $\begin{array}{c}-0.119 \\
(0.060) \dagger\end{array}$ & $\begin{array}{c}-0.012 \\
(0.035) \\
\end{array}$ & $\begin{array}{c}0.014 \\
(0.032) \\
\end{array}$ & $\begin{array}{c}0.080 \\
(0.051) \\
\end{array}$ \\
\hline $\begin{array}{c}\text { MEAN- } \\
\text { F_MEAN }\end{array}$ & $\begin{array}{c}0.271 \\
(0.218) \\
\end{array}$ & $\begin{array}{c}-0.132 \\
(0.083) \\
\end{array}$ & $\begin{array}{r}-0.025 \\
(0.117) \\
\end{array}$ & $\begin{array}{l}-0.067 \\
(0.076) \\
\end{array}$ & $\begin{array}{c}0.181 \\
(0.096) \dagger \\
\end{array}$ & $\begin{array}{c}0.241 \\
(0.060)^{*}\end{array}$ & $\begin{array}{c}0.235 \\
(0.058)^{*} \\
\end{array}$ & $\begin{array}{c}0.271 \\
(0.091)^{*} \\
\end{array}$ & $\begin{array}{c}0.306 \\
(0.138)^{* *} \\
\end{array}$ \\
\hline $\begin{array}{l}\text { POS1D- } \\
\text { NEG1D }\end{array}$ & $\begin{array}{c}0.075 \\
(0.215) \\
\end{array}$ & $\begin{array}{c}-0.055 \\
(0.339) \\
\end{array}$ & $\begin{array}{c}0.304 \\
(0.828) \\
\end{array}$ & $\begin{array}{c}-0.292 \\
(0.227) \\
\end{array}$ & $\begin{array}{c}-0.489 \\
(0.270) \dagger\end{array}$ & $\begin{array}{c}-0.094 \\
(0.092) \\
\end{array}$ & $\begin{array}{c}0.435 \\
(0.204)^{* *}\end{array}$ & $\begin{array}{l}-0.268 \\
(0.273) \\
\end{array}$ & $\begin{array}{c}0.205 \\
(0.219) \\
\end{array}$ \\
\hline $\begin{array}{c}\text { OILPRICEPC } \\
\mathrm{H} \\
\end{array}$ & $\begin{array}{c}-0.000 \\
(0.001) \\
\end{array}$ & $\begin{array}{c}-0.001 \\
(0.001) \\
\end{array}$ & $\begin{array}{c}0.001 \\
(0.002) \\
\end{array}$ & $\begin{array}{c}-0.000 \\
(0.001) \\
\end{array}$ & $\begin{array}{c}0.001 \\
(0.001) \\
\end{array}$ & $\begin{array}{c}0.002 \\
(0.001) \dagger \\
\end{array}$ & $\begin{array}{c}0.001 \\
(0.001) \\
\end{array}$ & $\begin{array}{c}0.001 \\
(0.001) \\
\end{array}$ & $\begin{array}{c}-0.003 \\
(0.002) \\
\end{array}$ \\
\hline VIX & $\begin{array}{c}-0.001 \\
(0.003) \\
\end{array}$ & $\begin{array}{c}0.009 \\
(0.002)^{*}\end{array}$ & $\begin{array}{c}0.002 \\
(0.004)\end{array}$ & $\begin{array}{c}0.003 \\
(0.002) \\
\end{array}$ & $\begin{array}{c}0.146 \\
(0.004)^{*}\end{array}$ & $\begin{array}{c}0.001 \\
(0.003) \\
\end{array}$ & $\begin{array}{c}0.005 \\
(0.003) \dagger \\
\end{array}$ & $\begin{array}{c}0.010 \\
(0.004)^{*}\end{array}$ & $\begin{array}{c}0.004 \\
(0.004) \\
\end{array}$ \\
\hline $\begin{array}{c}\text { Real Time } \\
\text { revisions }\end{array}$ & $\begin{array}{l}-0.015 \\
(0.028) \\
\end{array}$ & $\begin{array}{c}-0.007 \\
(0.017)\end{array}$ & $\begin{array}{c}-0.18 \\
(0.024)\end{array}$ & $\begin{array}{c}-0.032 \\
(0.013)^{* *}\end{array}$ & $\begin{array}{c}-0.040 \\
(0.016)^{* *}\end{array}$ & $\begin{array}{c}-0.028 \\
(0.016) \dagger\end{array}$ & $\begin{array}{c}-0.017 \\
(0.011)\end{array}$ & $\begin{array}{c}0.001 \\
(0.012)\end{array}$ & $\begin{array}{c}0.016 \\
(0.348)\end{array}$ \\
\hline$R$-squared: & 0.409 & 0.504 & 0.390 & 0.641 & 0.707 & 0.415 & 0.427 & 0.353 & 0.420 \\
\hline F-statistic: & 4.749 & 6.969 & 4.108 & 12.266 & 16.563 & 4.860 & 5.119 & 3.734 & 4.970 \\
\hline $\operatorname{Prob}(F$-stat): & 0.004 & 0.000 & 0.001 & 0.000 & 0.000 & 0.000 & 0.000 & 0.003 & 0.000 \\
\hline
\end{tabular}

Notes: The title refers to the benchmark used to calculate disagreement (equation (2)). Least squares estimation with heteroscedasticity and autocorrelation-consistent standard errors (HAC). The full sample is 2001Q1-2014Q4 when central bank communication variables are included, otherwise 1999Q1-2014Q4. * means statistically significant at the 1\% level; ** at the 5\% level; † at the $10 \%$ level. GAPQ is the domestic output gap, GLOBALGAP is the global output gap; PGAP is the headline versus core inflation differential; MEAN is the arithmetic mean of all domestic inflation forecasts and F_MEAN is the global inflation forecast; POS1D-NEG1D is the 
differential between positive and negative sentiment in central press releases issued following a policy rate decision (times 10); OILPRICEPCH is the rate of change (annualized) in the U.K. Brent price of crude per barrel; VIX is the Chicago Board Options Exchange (CBOE) implied volatility of S\&P 500 index. Real Time revisions is the accumulated revisions in the growth rate of the output gap. AUS=Australia, CAN=Canada, CHE=Switzerland, EUR=Eurozone, GBR=U.K., JPN=Japan, NZL=New Zealand, SWE= Sweden, USA=U.S.. 
Table 2b Determinants of Forecast Disagreement: Central Bank Forecasts

\begin{tabular}{|c|c|c|c|c|c|c|c|c|c|}
\hline Dep. Var: & AUS & CAN & CHE & EUR & GBR & JPN & NZL & SWE & USA \\
\hline C & $\begin{array}{l}-0.013 \\
(0.313) \\
\end{array}$ & $\begin{array}{c}0.211 \\
(0.270)\end{array}$ & $\begin{array}{c}0.256 \\
(0.177) \\
\end{array}$ & $\begin{array}{c}0.375 \\
(0.097)^{*}\end{array}$ & $\begin{array}{c}0.005 \\
(0.146) \\
\end{array}$ & $\begin{array}{c}0.709 \\
(0.113)^{*}\end{array}$ & $\begin{array}{c}0.062 \\
(0.099) \\
\end{array}$ & $\begin{array}{c}0.234 \\
(0.139) \dagger\end{array}$ & $\begin{array}{c}-0.251 \\
(0.144) \dagger\end{array}$ \\
\hline $\begin{array}{c}\text { GAPQ- } \\
\text { GLOBALGA } \\
\mathrm{P} \\
\end{array}$ & $\begin{array}{c}0.065 \\
(0.059) \\
\end{array}$ & $\begin{array}{c}-0.132 \\
(0.084)\end{array}$ & $\begin{array}{c}0.029 \\
(0.018) \\
\end{array}$ & $\begin{array}{c}0.181 \\
(0.041)^{*}\end{array}$ & $\begin{array}{c}0.048 \\
(0.020)^{* *}\end{array}$ & $\begin{array}{c}-0.017 \\
(0.044) \\
\end{array}$ & $\begin{array}{c}-0.022 \\
(0.019) \\
\end{array}$ & $\begin{array}{c}0.033 \\
(0.031) \\
\end{array}$ & $\begin{array}{c}-0.075 \\
(0.034)^{* *}\end{array}$ \\
\hline PGAP & $\begin{array}{c}0.302 \\
(0.110)^{*}\end{array}$ & $\begin{array}{c}0.035 \\
(0.050) \\
\end{array}$ & $\begin{array}{c}-0.019 \\
(0.091) \\
\end{array}$ & $\begin{array}{c}-0.115 \\
(0.034)^{*} \\
\end{array}$ & $\begin{array}{c}0.033 \\
(0.029)\end{array}$ & $\begin{array}{c}-0.080 \\
(0.071) \\
\end{array}$ & $\begin{array}{c}-0.032 \\
(0.037) \\
\end{array}$ & $\begin{array}{c}0.005 \\
(0.031) \\
\end{array}$ & $\begin{array}{c}0.067 \\
(0.047) \\
\end{array}$ \\
\hline $\begin{array}{c}\text { MEAN- } \\
\text { F_MEAN }\end{array}$ & $\begin{array}{c}0.163 \\
(0.415) \\
\end{array}$ & $\begin{array}{c}-0.253 \\
(0.141) \dagger \\
\end{array}$ & $\begin{array}{c}0.205 \\
(0.117) \dagger \\
\end{array}$ & $\begin{array}{l}-0.076 \\
(0.076) \\
\end{array}$ & $\begin{array}{c}0.090 \\
(0.053) \dagger\end{array}$ & $\begin{array}{c}0.377 \\
(0.073)^{*}\end{array}$ & $\begin{array}{c}0.204 \\
(0.060)^{*} \\
\end{array}$ & $\begin{array}{c}0.137 \\
(0.088) \\
\end{array}$ & $\begin{array}{c}0.254 \\
(0.128)^{* *}\end{array}$ \\
\hline $\begin{array}{l}\text { POS1D- } \\
\text { NEG1D }\end{array}$ & $\begin{array}{c}-0.091 \\
(0.461) \\
\end{array}$ & $\begin{array}{c}0.401 \\
(0.480) \\
\end{array}$ & $\begin{array}{c}0.793 \\
(0.848) \\
\end{array}$ & $\begin{array}{c}-0.312 \\
(0.225) \\
\end{array}$ & $\begin{array}{c}-0.228 \\
(0.148) \\
\end{array}$ & $\begin{array}{c}0.016 \\
(0.109) \\
\end{array}$ & $\begin{array}{c}0.292 \\
(0.212) \\
\end{array}$ & $\begin{array}{c}-0.216 \\
(0.264) \\
\end{array}$ & $\begin{array}{c}0.247 \\
(0.203) \\
\end{array}$ \\
\hline $\begin{array}{c}\text { OILPRICEPC } \\
\mathrm{H} \\
\end{array}$ & $\begin{array}{c}-0.001 \\
(0.002) \\
\end{array}$ & $\begin{array}{c}-0.004 \\
(0.001)^{*}\end{array}$ & $\begin{array}{c}-0.000 \\
(0.002) \\
\end{array}$ & $\begin{array}{c}0.000 \\
(0.008) \\
\end{array}$ & $\begin{array}{c}0.000 \\
(0.005) \\
\end{array}$ & $\begin{array}{c}0.002 \\
(0.001) \\
\end{array}$ & $\begin{array}{c}0.002 \\
(0.001) \\
\end{array}$ & $\begin{array}{c}-0.001 \\
(0.001) \\
\end{array}$ & $\begin{array}{c}0.001 \\
(0.002) \\
\end{array}$ \\
\hline VIX & $\begin{array}{c}0.005 \\
(0.006) \\
\end{array}$ & $\begin{array}{c}0.007 \\
(0.004)^{* *}\end{array}$ & $\begin{array}{c}0.006 \\
(0.004) \\
\end{array}$ & $\begin{array}{l}-0.002 \\
(0.002)\end{array}$ & $\begin{array}{c}0.012 \\
(0.002)^{*}\end{array}$ & $\begin{array}{c}0.005 \\
(0.004) \\
\end{array}$ & $\begin{array}{c}0.004 \\
(0.003) \\
\end{array}$ & $\begin{array}{c}0.008 \\
(0.004)^{* *}\end{array}$ & $\begin{array}{c}0.003 \\
(0.004) \\
\end{array}$ \\
\hline $\begin{array}{l}\text { Real Time } \\
\text { revisions }\end{array}$ & $\begin{array}{c}-0.011 \\
(0.066)\end{array}$ & $\begin{array}{l}-0.033 \\
(0.024)\end{array}$ & $\begin{array}{c}-0.150 \\
(0.023)\end{array}$ & $\begin{array}{l}-0.035 \\
(0.013)\end{array}$ & $\begin{array}{c}-0.018 \\
(0.089)^{* *}\end{array}$ & $\begin{array}{c}-0.012 \\
(0.018)\end{array}$ & $\begin{array}{c}-0.038 \\
(0.011)^{*}\end{array}$ & $\begin{array}{c}0.002 \\
(0.012)\end{array}$ & $\begin{array}{c}0.030 \\
(0.017) \dagger\end{array}$ \\
\hline R-squared: & 0.475 & 0.623 & 0.334 & 0.610 & 0.788 & 0.560 & 0.410 & 0.202 & 0.480 \\
\hline F-statistic: & 3.106 & 7.095 & 2.649 & 10.719 & 25.443 & 8.347 & 4.777 & 1.734 & 6.327 \\
\hline $\operatorname{Prob}(F$-stat): & 0.018 & 0.000 & 0.025 & 0.000 & 0.000 & 0.000 & 0.000 & 0.123 & 0.000 \\
\hline
\end{tabular}

Note: See note to Table 2a. 
TABLE 2c BENCHMARK: Determinants of Forecast Disagreement: Households and Firms Forecasts

\begin{tabular}{|c|c|c|c|c|c|c|c|c|c|}
\hline Dep. Var: & AUS & CAN & $\mathrm{CHE}$ & EUR & GBR & JPN & NZL & SWE & USA \\
\hline $\mathrm{C}$ & $\begin{array}{l}-0.208 \\
(0.169) \\
\end{array}$ & $\begin{array}{c}0.070 \\
(0.162) \\
\end{array}$ & $\begin{array}{l}-0.152 \\
(0.307) \\
\end{array}$ & $\begin{array}{c}0.310 \\
(0.095)^{*}\end{array}$ & $\begin{array}{c}0.162 \\
(0.288) \\
\end{array}$ & $\begin{array}{c}0.681 \\
(0.085)^{*}\end{array}$ & $\begin{array}{c}0.051 \\
(0.145) \\
\end{array}$ & $\begin{array}{c}0.442 \\
(0.162)^{*}\end{array}$ & $\begin{array}{c}-0.364 \\
(0.126)^{*}\end{array}$ \\
\hline \begin{tabular}{|c|} 
GAPQ- \\
GLOBALGA \\
$\mathrm{P}$ \\
\end{tabular} & $\begin{array}{c}0.036 \\
(0.022) \dagger\end{array}$ & $\begin{array}{l}-0.026 \\
(0.044)\end{array}$ & $\begin{array}{c}0.073 \\
(0.039) \dagger\end{array}$ & $\begin{array}{c}0.184 \\
(0.040)^{*}\end{array}$ & $\begin{array}{c}0.145 \\
(0.039)^{*}\end{array}$ & $\begin{array}{c}0.005 \\
(0.034)\end{array}$ & $\begin{array}{c}0.001 \\
(0.028)\end{array}$ & $\begin{array}{c}0.017 \\
(0.036)\end{array}$ & $\begin{array}{c}-0.090 \\
(0.030)^{*}\end{array}$ \\
\hline PGAP & $\begin{array}{c}0.151 \\
(0.053)^{*} \\
\end{array}$ & $\begin{array}{c}0.005 \\
(0.029) \\
\end{array}$ & $\begin{array}{c}-0.248 \\
(0.138) \dagger\end{array}$ & $\begin{array}{c}-0.135 \\
(0.034)^{*}\end{array}$ & $\begin{array}{c}-0.058 \\
(0.056) \\
\end{array}$ & $\begin{array}{c}-0.092 \\
(0.054) \dagger \\
\end{array}$ & $\begin{array}{c}0.105 \\
(0.054) \dagger \\
\end{array}$ & $\begin{array}{c}0.015 \\
(0.036) \\
\end{array}$ & $\begin{array}{c}0.069 \\
(0.041)^{* *}\end{array}$ \\
\hline $\begin{array}{c}\text { MEAN- } \\
\text { F_MEAN }\end{array}$ & $\begin{array}{c}0.392 \\
(0.205) \dagger\end{array}$ & $\begin{array}{l}-0.073 \\
(0.075) \\
\end{array}$ & $\begin{array}{l}-0.187 \\
(0.176)\end{array}$ & $\begin{array}{c}-0.062 \\
(0.074)\end{array}$ & $\begin{array}{c}0.239 \\
(0.104)^{* *}\end{array}$ & $\begin{array}{c}0.225 \\
(0.054)^{*}\end{array}$ & $\begin{array}{l}-0.127 \\
(0.088)\end{array}$ & $\begin{array}{c}0.379 \\
(0.103)^{*}\end{array}$ & $\begin{array}{c}0.365 \\
(0.112)^{*}\end{array}$ \\
\hline $\begin{array}{l}\text { POS1D- } \\
\text { NEG1D }\end{array}$ & $\begin{array}{c}0.198 \\
(0.202) \\
\end{array}$ & $\begin{array}{l}-0.028 \\
(0.327) \\
\end{array}$ & $\begin{array}{r}-0.423 \\
(13.04) \\
\end{array}$ & $\begin{array}{c}-0.242 \\
(0.221)\end{array}$ & $\begin{array}{c}-0.473 \\
(0.292) \\
\end{array}$ & $\begin{array}{l}-0.066 \\
(0.084) \\
\end{array}$ & $\begin{array}{c}0.271 \\
(0.310) \\
\end{array}$ & $\begin{array}{l}-0.214 \\
(0.309) \\
\end{array}$ & $\begin{array}{c}0.268 \\
(0.177) \\
\end{array}$ \\
\hline \begin{tabular}{|c|} 
OILPRICEPC \\
$\mathrm{H}$ \\
\end{tabular} & $\begin{array}{c}0.000 \\
(0.001) \\
\end{array}$ & $\begin{array}{c}-0.002 \\
(0.001)^{* *}\end{array}$ & $\begin{array}{c}0.001 \\
(0.003) \\
\end{array}$ & $\begin{array}{c}0.001 \\
(0.001) \\
\end{array}$ & $\begin{array}{c}0.002 \\
(0.001) \\
\end{array}$ & $\begin{array}{c}0.001 \\
(0.001) \\
\end{array}$ & $\begin{array}{c}-0.003 \\
(0.001)^{* *}\end{array}$ & $\begin{array}{c}0.001 \\
(0.002) \\
\end{array}$ & $\begin{array}{c}0.000 \\
(0.002) \\
\end{array}$ \\
\hline VIX & $\begin{array}{c}-0.001 \\
(0.003) \\
\end{array}$ & $\begin{array}{c}0.007 \\
(0.002)^{*}\end{array}$ & $\begin{array}{c}-0.002 \\
(0.006) \\
\end{array}$ & $\begin{array}{c}-0.002 \\
(0.002) \\
\end{array}$ & $\begin{array}{c}0.013 \\
(0.004)^{*} \\
\end{array}$ & $\begin{array}{c}0.001 \\
(0.003) \\
\end{array}$ & $\begin{array}{c}0.014 \\
(0.004)^{*}\end{array}$ & $\begin{array}{c}0.009 \\
(0.004)^{* *}\end{array}$ & $\begin{array}{c}0.004 \\
(0.003) \\
\end{array}$ \\
\hline $\begin{array}{c}\text { Real Time } \\
\text { revisions }\end{array}$ & $\begin{array}{l}-0.003 \\
(0.026) \\
\end{array}$ & $\begin{array}{c}-0.012 \\
(0.015) \\
\end{array}$ & $\begin{array}{c}0.075 \\
(0.041) \dagger \\
\end{array}$ & $\begin{array}{c}-0.033 \\
(0.013)^{*}\end{array}$ & $\begin{array}{c}-0.034 \\
(0.017) \dagger \\
\end{array}$ & $\begin{array}{c}-0.021 \\
(0.014) \\
\end{array}$ & $\begin{array}{c}0.033 \\
(0.017)^{* *}\end{array}$ & $\begin{array}{c}0.013 \\
(0.014) \\
\end{array}$ & $\begin{array}{c}0.022 \\
(0.015) \\
\end{array}$ \\
\hline$R$-squared: & 0.384 & 0.454 & 0.281 & 0.602 & 0.663 & 0.462 & 0.384 & 0.385 & 0.579 \\
\hline F-statistic: & 4.277 & 5.352 & 1.287 & 10.369 & 13.515 & 5.899 & 4.272 & 4.298 & 9.448 \\
\hline $\operatorname{Prob}(F$-stat): & 0.001 & 0.000 & 0.300 & 0.000 & 0.000 & 0.000 & 0.001 & 0.001 & 0.000 \\
\hline
\end{tabular}

Note: See notes to Table 2a. 
Table 3a Determinants of Forecast Disagreement: Maximum Levels of Disagreement

\begin{tabular}{|c|c|c|c|c|c|c|c|c|c|}
\hline Dep. Var: & AUS-MAX & CAN-MAX & CHE-MAX & EUR-MAX & GBR-MAX & JPN-MAX & NZL-MAX & SWE-MAX & USA-MAX \\
\hline C & $\begin{array}{l}-0.117 \\
(0.197) \\
\end{array}$ & $\begin{array}{c}0.171 \\
(0.195)\end{array}$ & $\begin{array}{c}0.248 \\
(0.195)\end{array}$ & $\begin{array}{c}0.363 \\
(0.104)^{*}\end{array}$ & $\begin{array}{c}0.402 \\
(0.329) \\
\end{array}$ & $\begin{array}{c}1.039 \\
(0.108)^{*}\end{array}$ & $\begin{array}{l}-0.011 \\
(0.147) \\
\end{array}$ & $\begin{array}{c}0.442 \\
(0.160)^{*}\end{array}$ & $\begin{array}{l}-0.237 \\
(0.166) \\
\end{array}$ \\
\hline \begin{tabular}{|c|} 
GAPQ- \\
GLOBALGA \\
P \\
\end{tabular} & $\begin{array}{c}0.074 \\
(0.025)^{*}\end{array}$ & $\begin{array}{c}-0.033 \\
(0.055)\end{array}$ & $\begin{array}{c}0.058 \\
(0.021)^{*}\end{array}$ & $\begin{array}{c}0.180 \\
(0.044)^{*}\end{array}$ & $\begin{array}{c}0.119 \\
(0.045)^{*}\end{array}$ & $\begin{array}{c}-0.011 \\
(0.044)\end{array}$ & $\begin{array}{c}0.007 \\
(0.029)\end{array}$ & $\begin{array}{c}0.027 \\
(0.036)\end{array}$ & $\begin{array}{c}-0.087 \\
(0.039)^{* *}\end{array}$ \\
\hline PGAP & $\begin{array}{c}0.228 \\
(0.061)^{*}\end{array}$ & $\begin{array}{l}-0.050 \\
(0.035) \\
\end{array}$ & $\begin{array}{c}-0.090 \\
(0.105)\end{array}$ & $\begin{array}{c}-0.103 \\
(0.037)^{*}\end{array}$ & $\begin{array}{r}-0.003 \\
(0.064)\end{array}$ & $\begin{array}{l}-0.105 \\
(0.070)\end{array}$ & $\begin{array}{c}0.045 \\
(0.055) \\
\end{array}$ & $\begin{array}{c}0.014 \\
(0.035)\end{array}$ & $\begin{array}{c}0.097 \\
(0.055) \dagger\end{array}$ \\
\hline $\begin{array}{l}\text { MEAN- } \\
\text { F_MEAN }\end{array}$ & $\begin{array}{c}0.187 \\
(0.238)\end{array}$ & $\begin{array}{c}-0.177 \\
(0.094) \dagger\end{array}$ & $\begin{array}{l}-0.015 \\
(0.135)\end{array}$ & $\begin{array}{c}-0.090 \\
(0.081)\end{array}$ & $\begin{array}{c}0.152 \\
(0.119)\end{array}$ & $\begin{array}{c}0.263 \\
(0.070)^{*}\end{array}$ & $\begin{array}{c}0.108 \\
(0.090)\end{array}$ & $\begin{array}{c}0.276 \\
(0.101)^{*}\end{array}$ & $\begin{array}{c}0.337 \\
(0.148)^{* *}\end{array}$ \\
\hline $\begin{array}{l}\text { POS1D- } \\
\text { NEG1D }\end{array}$ & $\begin{array}{c}0.170 \\
(0.235) \\
\end{array}$ & $\begin{array}{l}-0.119 \\
(0.383) \\
\end{array}$ & $\begin{array}{c}0.168 \\
(0.951) \\
\end{array}$ & $\begin{array}{l}-0.325 \\
(0.242) \\
\end{array}$ & $\begin{array}{l}-0.535 \\
(0.333) \\
\end{array}$ & $\begin{array}{c}-0.348 \\
(0.108)^{*}\end{array}$ & $\begin{array}{c}0.374 \\
(0.316) \\
\end{array}$ & $\begin{array}{l}-0.263 \\
(0.305) \\
\end{array}$ & $\begin{array}{c}0.193 \\
(0.232) \\
\end{array}$ \\
\hline \begin{tabular}{|c|} 
OILPRICEPC \\
$\mathrm{H}$ \\
\end{tabular} & $\begin{array}{l}-0.000 \\
(0.001) \\
\end{array}$ & $\begin{array}{c}-0.001 \\
(0.001)\end{array}$ & $\begin{array}{l}-0.000 \\
(0.002) \\
\end{array}$ & $\begin{array}{c}-0.000 \\
(0.001) \\
\end{array}$ & $\begin{array}{c}0.001 \\
(0.001) \\
\end{array}$ & $\begin{array}{c}0.000 \\
(0.001) \\
\end{array}$ & $\begin{array}{c}-0.002 \\
(0.001) \\
\end{array}$ & $\begin{array}{c}0.000 \\
(0.001)\end{array}$ & $\begin{array}{l}-0.000 \\
(0.002)\end{array}$ \\
\hline VIX & $\begin{array}{c}0.004 \\
(0.004) \\
\end{array}$ & $\begin{array}{c}0.011 \\
(0.003)^{*}\end{array}$ & $\begin{array}{c}0.004 \\
(0.004) \\
\end{array}$ & $\begin{array}{c}0.000 \\
(0.003) \\
\end{array}$ & $\begin{array}{c}0.015 \\
(0.005)^{*}\end{array}$ & $\begin{array}{c}0.000 \\
(0.004) \\
\end{array}$ & $\begin{array}{c}0.012 \\
(0.004)^{*}\end{array}$ & $\begin{array}{c}0.010 \\
(0.004)^{* *} \\
\end{array}$ & $\begin{array}{c}0.004 \\
(0.004) \\
\end{array}$ \\
\hline $\begin{array}{c}\text { Real Time } \\
\text { revisions }\end{array}$ & $\begin{array}{c}0.010 \\
(0.030) \\
\end{array}$ & $\begin{array}{l}-0.018 \\
(0.019) \\
\end{array}$ & $\begin{array}{l}-0.037 \\
(0.027) \\
\end{array}$ & $\begin{array}{c}-0.034 \\
(0.014)^{* *}\end{array}$ & $\begin{array}{c}-0.057 \\
(0.020)^{*} \\
\end{array}$ & $\begin{array}{c}-0.004 \\
(0.018)^{* *}\end{array}$ & $\begin{array}{c}0.020 \\
(0.017) \\
\end{array}$ & $\begin{array}{c}0.006 \\
(0.014) \\
\end{array}$ & $\begin{array}{c}0.014 \\
(0.020) \\
\end{array}$ \\
\hline$R$-squared: & 0.481 & 0.550 & 0.392 & 0.610 & 0657 & 0.478 & 0.311 & 0.294 & 0.419 \\
\hline F-statistic: & 6.352 & 8.397 & 4.138 & 10.724 & 13.141 & 6.275 & 3.094 & 2.849 & 4.951 \\
\hline $\operatorname{Prob}(F$-stat): & 0.000 & 0.000 & 0.001 & 0.000 & 0.000 & 0.000 & 0.001 & 0.014 & 0.000 \\
\hline
\end{tabular}

Notes: See Notes to Table 2a. The benchmark is ALL forecasts. MAX is the highest level of disagreement at time $t$ in each economy. See Figure 3. 
Table 3b Determinants of Forecast Disagreement: Mean Levels of Disagreement

\begin{tabular}{|c|c|c|c|c|c|c|c|c|c|}
\hline Dep. Var: & AUS-MEAN & CAN-MEAN & CHE-MEAN & EUR-MEAN & GBR-MEAN & JPN-MEAN & NZL-MEAN & SWE-MEAN & USA-MEAN \\
\hline C & $\begin{array}{l}-0.100 \\
(0.151)\end{array}$ & $\begin{array}{c}0.116 \\
(0.166)\end{array}$ & $\begin{array}{c}0.180 \\
(0.155)\end{array}$ & $\begin{array}{c}0.335 \\
(0.097)^{*}\end{array}$ & $\begin{array}{c}0.262 \\
(0.242)\end{array}$ & $\begin{array}{c}0.737 \\
(0.087)^{*}\end{array}$ & $\begin{array}{l}-0.018 \\
(0.093)\end{array}$ & $\begin{array}{c}0.315 \\
(0.125)^{* *}\end{array}$ & $\begin{array}{c}-0.281 \\
(0.148) \dagger\end{array}$ \\
\hline \begin{tabular}{|c|} 
GAPQ- \\
GLOBALGA \\
$\mathrm{P}$ \\
\end{tabular} & $\begin{array}{c}0.051 \\
(0.019)^{*}\end{array}$ & $\begin{array}{c}-0.025 \\
(0.047)\end{array}$ & $\begin{array}{c}0.047 \\
(0.016)^{*}\end{array}$ & $\begin{array}{c}0.172 \\
(0.041)^{*}\end{array}$ & $\begin{array}{c}0.101 \\
(0.033)^{*}\end{array}$ & $\begin{array}{c}0.002 \\
(0.035)\end{array}$ & $\begin{array}{c}-0.006 \\
(0.018)\end{array}$ & $\begin{array}{c}0.018 \\
(0.028)\end{array}$ & $\begin{array}{c}-0.093 \\
(0.035)^{*}\end{array}$ \\
\hline PGAP & $\begin{array}{c}0.158 \\
(0.047)^{*}\end{array}$ & $\begin{array}{c}-0.037 \\
(0.030) \\
\end{array}$ & $\begin{array}{l}-0.106 \\
(0.083) \\
\end{array}$ & $\begin{array}{c}-0.122 \\
(0.034)^{*}\end{array}$ & $\begin{array}{c}-0.012 \\
(0.047)\end{array}$ & $\begin{array}{c}-0.095 \\
(0.056) \dagger\end{array}$ & $\begin{array}{c}0.008 \\
(0.035)\end{array}$ & $\begin{array}{c}0.009 \\
(0.028)\end{array}$ & $\begin{array}{c}0.080 \\
(0.049) \\
\end{array}$ \\
\hline $\begin{array}{c}\text { MEAN- } \\
\text { F_MEAN }\end{array}$ & $\begin{array}{c}0.246 \\
(0.183)\end{array}$ & $\begin{array}{c}-0.148 \\
(0.080) \dagger\end{array}$ & $\begin{array}{l}-0.019 \\
(0.107)\end{array}$ & $\begin{array}{l}-0.0733 \\
(0.0754) \\
\end{array}$ & $\begin{array}{c}0.164 \\
(0.087) \dagger\end{array}$ & $\begin{array}{c}0.221 \\
(0.055)^{*}\end{array}$ & $\begin{array}{c}0.165 \\
(0.057)^{*}\end{array}$ & $\begin{array}{c}0.225 \\
(0.079)^{*}\end{array}$ & $\begin{array}{c}0.308 \\
(0.132)^{* *}\end{array}$ \\
\hline $\begin{array}{l}\text { POS1D- } \\
\text { NEG1D }\end{array}$ & $\begin{array}{c}0.109 \\
(0.180) \\
\end{array}$ & $\begin{array}{c}-0.090 \\
(0.327) \\
\end{array}$ & $\begin{array}{c}0.239 \\
(0.755) \\
\end{array}$ & $\begin{array}{c}-0.293 \\
(0.225) \\
\end{array}$ & $\begin{array}{c}-0.461 \\
(0.245) \dagger \\
\end{array}$ & $\begin{array}{c}-0.152 \\
(0.086) \dagger \\
\end{array}$ & $\begin{array}{c}0.365 \\
(0.201) \dagger \\
\end{array}$ & $\begin{array}{l}-0.227 \\
(0.238) \\
\end{array}$ & $\begin{array}{c}0.220 \\
(0.209) \\
\end{array}$ \\
\hline \begin{tabular}{|c|} 
OILPRICEPC \\
$\mathrm{H}$ \\
\end{tabular} & $\begin{array}{c}-0.000 \\
(0.001) \\
\end{array}$ & $\begin{array}{c}-0.001 \\
(0.001) \\
\end{array}$ & $\begin{array}{c}0.000 \\
(0.002) \\
\end{array}$ & $\begin{array}{c}0.000 \\
(0.001) \\
\end{array}$ & $\begin{array}{c}0.001 \\
(0.001) \\
\end{array}$ & $\begin{array}{c}0.001 \\
(0.001) \\
\end{array}$ & $\begin{array}{c}0.000 \\
(0.001) \\
\end{array}$ & $\begin{array}{c}0.000 \\
(0.001) \\
\end{array}$ & $\begin{array}{c}-0.000 \\
(0.002) \\
\end{array}$ \\
\hline VIX & $\begin{array}{c}0.000 \\
(0.003)\end{array}$ & $\begin{array}{c}0.009 \\
(0.002)^{*}\end{array}$ & $\begin{array}{c}0.002 \\
(0.003)\end{array}$ & $\begin{array}{l}-0.005 \\
(0.002)\end{array}$ & $\begin{array}{c}0.012 \\
(0.004)^{*}\end{array}$ & $\begin{array}{c}0.001 \\
(0.003)\end{array}$ & $\begin{array}{c}0.006 \\
(0.003)^{* *}\end{array}$ & $\begin{array}{c}0.009 \\
(0.003)^{*}\end{array}$ & $\begin{array}{c}0.004 \\
(0.004)\end{array}$ \\
\hline $\begin{array}{c}\text { Real Time } \\
\text { revisions }\end{array}$ & $\begin{array}{l}-0.004 \\
(0.023) \\
\end{array}$ & $\begin{array}{c}-0.012 \\
(0.016) \\
\end{array}$ & $\begin{array}{l}-0.019 \\
(0.022) \\
\end{array}$ & $\begin{array}{c}-0.032 \\
(0.013)^{* *}\end{array}$ & $\begin{array}{c}-0.038 \\
(0.014)^{*}\end{array}$ & $\begin{array}{c}-0.028 \\
(0.015) \dagger \\
\end{array}$ & $\begin{array}{c}-0.010 \\
(0.011) \\
\end{array}$ & $\begin{array}{c}0.001 \\
(0.011) \\
\end{array}$ & $\begin{array}{c}0.018 \\
(0.018) \\
\end{array}$ \\
\hline R-squared: & 0.429 & 0.535 & 0.375 & 0.629 & 0.696 & 0.445 & 0.356 & 0.335 & 0.456 \\
\hline F-statistic: & 5.145 & 7.896 & 3.853 & 11.601 & 15.666 & 5.500 & 3.785 & 3.460 & 5.746 \\
\hline $\operatorname{Prob}($ F-stat): & 0.000 & 0.000 & 0.002 & 0.000 & 0.000 & 0.000 & 0.002 & 0.004 & 0.000 \\
\hline
\end{tabular}

Notes: See Notes to Table 3a. 
TABLE 3c Determinants of Forecast Disagreement: Minimum Levels of Disagreement

\begin{tabular}{|c|c|c|c|c|c|c|c|c|}
\hline Dep. Var: & AUS-MIN & CAN-MIN & CHE-MIN & EUR-MIN & GBR-MIN & JPN-MIN & NZL-MIN & SWE-MIN \\
\hline $\mathrm{C}$ & $\begin{array}{l}-0.020 \\
(0.066)\end{array}$ & $\begin{array}{c}0.086 \\
(0.153)\end{array}$ & $\begin{array}{c}0.085 \\
(0.107)\end{array}$ & $\begin{array}{c}0.307 \\
(0.095)^{*}\end{array}$ & $\begin{array}{c}0.038 \\
(0.132)\end{array}$ & $\begin{array}{c}0.500 \\
(0.071)^{*}\end{array}$ & $\begin{array}{c}0.011 \\
(0.059)\end{array}$ & $\begin{array}{c}0.249 \\
(0.081)^{*}\end{array}$ \\
\hline \begin{tabular}{|c|} 
GAPQ- \\
GLOBALGA \\
$\mathrm{P}$ \\
\end{tabular} & $\begin{array}{c}0.015 \\
(0.008) \dagger \\
\end{array}$ & $\begin{array}{l}-0.023 \\
(0.043) \\
\end{array}$ & $\begin{array}{c}0.027 \\
(0.011)^{* *} \\
\end{array}$ & $\begin{array}{c}0.179 \\
(0.040)^{*} \\
\end{array}$ & $\begin{array}{c}0.054 \\
(0.018)^{*} \\
\end{array}$ & $\begin{array}{l}-0.028 \\
(0.028) \\
\end{array}$ & $\begin{array}{l}-0.013 \\
(0.011) \\
\end{array}$ & $\begin{array}{c}0.001 \\
(0.018) \\
\end{array}$ \\
\hline PGAP & $\begin{array}{c}0.056 \\
(0.020)^{*}\end{array}$ & $\begin{array}{c}-0.008 \\
(0.028)\end{array}$ & $\begin{array}{c}-0.109 \\
(0.058) \dagger\end{array}$ & $\begin{array}{c}-0.137 \\
(0.034)^{*}\end{array}$ & $\begin{array}{c}0.013 \\
(0.026) \\
\end{array}$ & $\begin{array}{c}-0.095 \\
(0.045)^{* *}\end{array}$ & $\begin{array}{c}0.017 \\
(0.022) \\
\end{array}$ & $\begin{array}{c}0.006 \\
(0.018) \\
\end{array}$ \\
\hline $\begin{array}{c}\text { MEAN- } \\
\text { F_MEAN }\end{array}$ & $\begin{array}{c}0.111 \\
(0.080) \\
\end{array}$ & $\begin{array}{c}-0.082 \\
(0.073) \\
\end{array}$ & $\begin{array}{c}-0.001 \\
(0.074) \\
\end{array}$ & $\begin{array}{l}-0.060 \\
(0.074) \\
\end{array}$ & $\begin{array}{c}0.100 \\
(0.048)^{* *} \\
\end{array}$ & $\begin{array}{c}0.227 \\
(0.045)^{*}\end{array}$ & $\begin{array}{c}0.051 \\
(0.036) \\
\end{array}$ & $\begin{array}{c}0.177 \\
(0.051)^{*}\end{array}$ \\
\hline $\begin{array}{l}\text { POS1D- } \\
\text { NEG1D }\end{array}$ & $\begin{array}{c}0.044 \\
(0.078) \\
\end{array}$ & $\begin{array}{l}-0.103 \\
(0.300) \\
\end{array}$ & $\begin{array}{c}0.438 \\
(0.524) \\
\end{array}$ & $\begin{array}{l}-0.250 \\
(0.221)\end{array}$ & $\begin{array}{c}-0.194 \\
(0.134) \\
\end{array}$ & $\begin{array}{c}-0.024 \\
(0.070)\end{array}$ & $\begin{array}{c}0.224 \\
(0.126) \dagger\end{array}$ & $\begin{array}{c}-0.194 \\
(0.155) \\
\end{array}$ \\
\hline \begin{tabular}{|c|} 
OILPRICEPC \\
$\mathrm{H}$ \\
\end{tabular} & $\begin{array}{l}-0.000 \\
(0.003) \\
\end{array}$ & $\begin{array}{c}-0.001 \\
(0.0008) \dagger \\
\end{array}$ & $\begin{array}{c}0.001 \\
(0.001) \\
\end{array}$ & $\begin{array}{c}0.001 \\
(0.001) \\
\end{array}$ & $\begin{array}{c}0.000 \\
(0.004) \\
\end{array}$ & $\begin{array}{c}0.001 \\
(0.001) \\
\end{array}$ & $\begin{array}{c}0.000 \\
(0.001) \\
\end{array}$ & $\begin{array}{c}0.000 \\
(0.001)\end{array}$ \\
\hline VIX & $\begin{array}{c}-0.000 \\
(0.001) \\
\end{array}$ & $\begin{array}{c}0.006 \\
(0.002)^{*} \\
\end{array}$ & $\begin{array}{c}0.001 \\
(0.002) \\
\end{array}$ & $\begin{array}{l}-0.002 \\
(0.002) \\
\end{array}$ & $\begin{array}{c}0.009 \\
(0.002)^{*}\end{array}$ & $\begin{array}{c}0.003 \\
(0.003) \\
\end{array}$ & $\begin{array}{c}0.004 \\
(0.002)^{* *}\end{array}$ & $\begin{array}{c}0.003 \\
(0.002)\end{array}$ \\
\hline $\begin{array}{c}\text { Real Time } \\
\text { revisions }\end{array}$ & $\begin{array}{l}-0.012 \\
(0.010)\end{array}$ & $\begin{array}{l}-0.012 \\
(0.015)\end{array}$ & $\begin{array}{c}-0.001 \\
(0.015) \\
\end{array}$ & $\begin{array}{c}-0.031 \\
(0.013)^{* *}\end{array}$ & $\begin{array}{c}-0.018 \\
(0.008)^{* *}\end{array}$ & $\begin{array}{l}-0.018 \\
(0.012) \\
\end{array}$ & $\begin{array}{l}-0.010 \\
(0.007) \\
\end{array}$ & $\begin{array}{c}0.003 \\
(0.007) \\
\end{array}$ \\
\hline$R$-squared: & 0.353 & 0.433 & 0.293 & 0.599 & 0.741 & 0.478 & 0.358 & 0.311 \\
\hline F-statistic: & 3.743 & 5.247 & 2.659 & 10.244 & 19.599 & 6.279 & 3.822 & 3.092 \\
\hline $\operatorname{Prob}(F$-stat): & 0.003 & 0.000 & 0.022 & 0.000 & 0.000 & 0.000 & 0.002 & 0.001 \\
\hline
\end{tabular}

Note: See Notes to Table 3a.

Figure 1 Headline Inflation and the Mean of Inflation Forecasts 

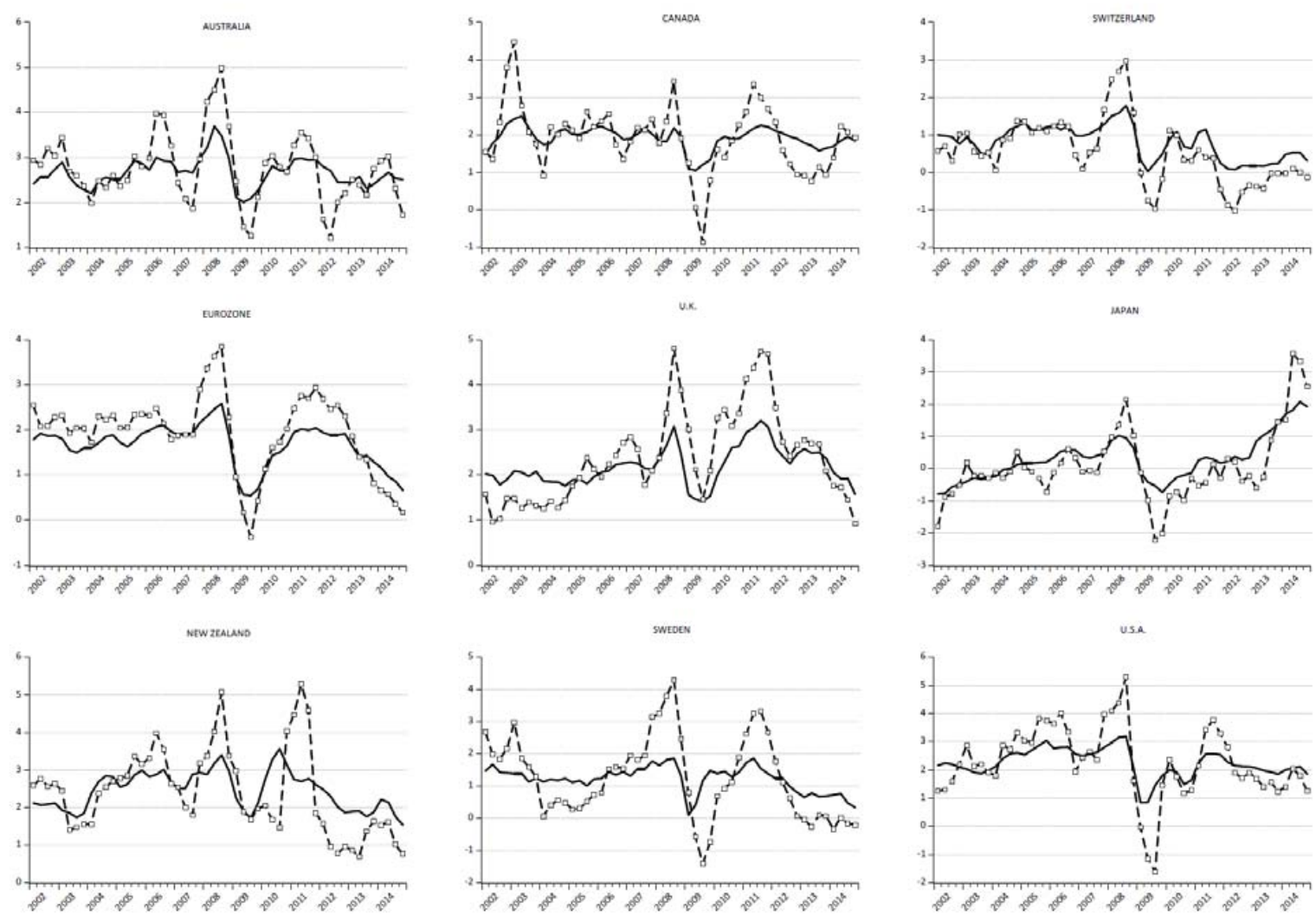

Note: Inflation is annualized log change in CPI Headline and Core (excludes energy, food, and indirect taxes). The mean of all available forecasts is used. 
Figure 2 Headline Inflation and the First Principal Component of Inflation Forecasts
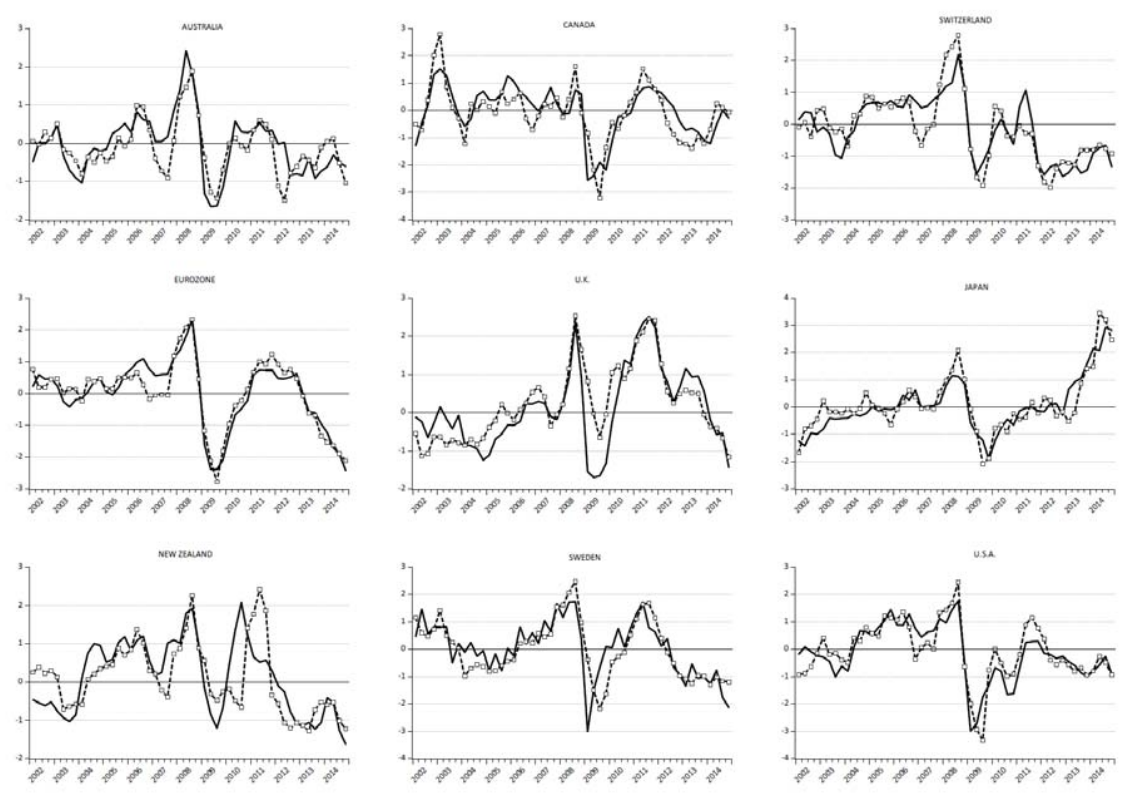

Note: The first principal component is estimated over an unbalanced panel of all available inflation forecasts. Estimation is based on principal factors with the number of factors estimated via the Kaiser-Guttman approach. Headline inflation is defined in Figure 1. For 
the U.S. the full sample excludes the Greenbook forecasts and forecasts from the Atlanta Federal Bank survey; for the U.K. full sample estimates exclude MPC staff estimate. 
Figure 3 Real Time Revisions Over Time
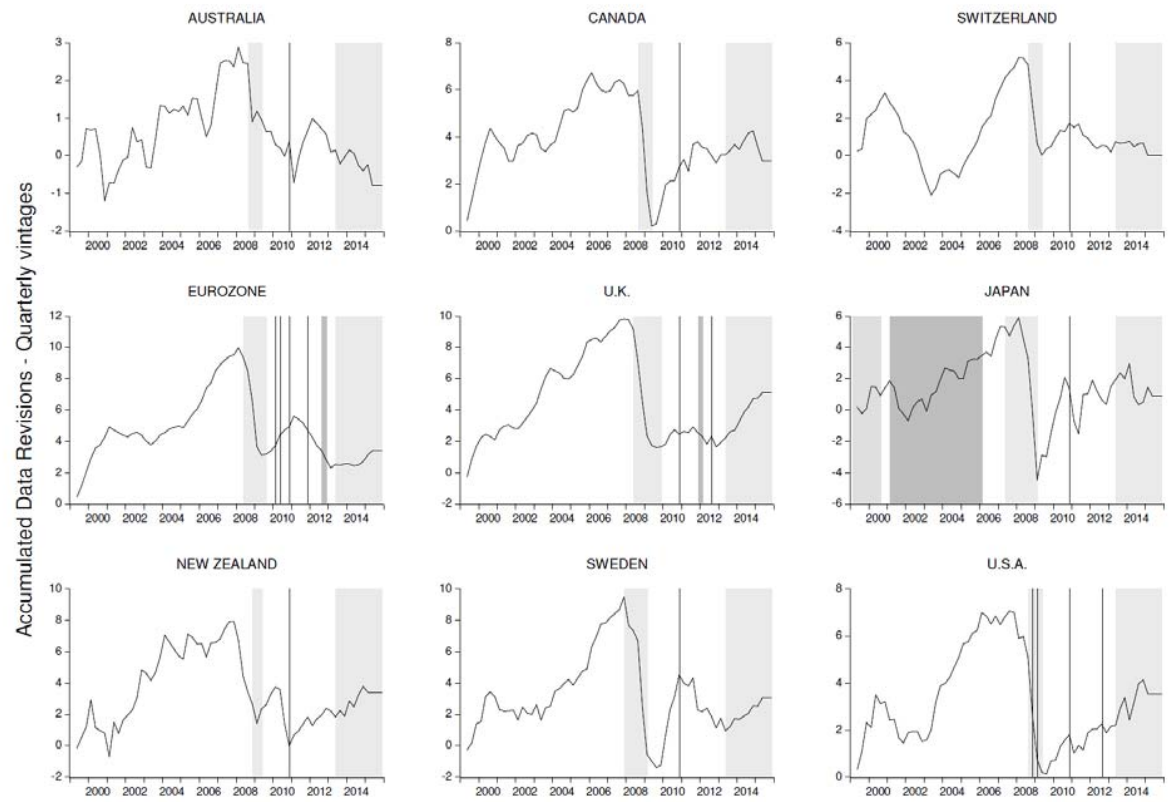

Note: The output gap is first estimated using an HP filter (smoothing parameter of 100,000). The change in growth rate of the output gap for quarterly vintages since 1999 (where available) is then evaluated and cumulated over time. 
Figure 4 Quasi-Confidence Intervals for Inflation Forecast Disagreement
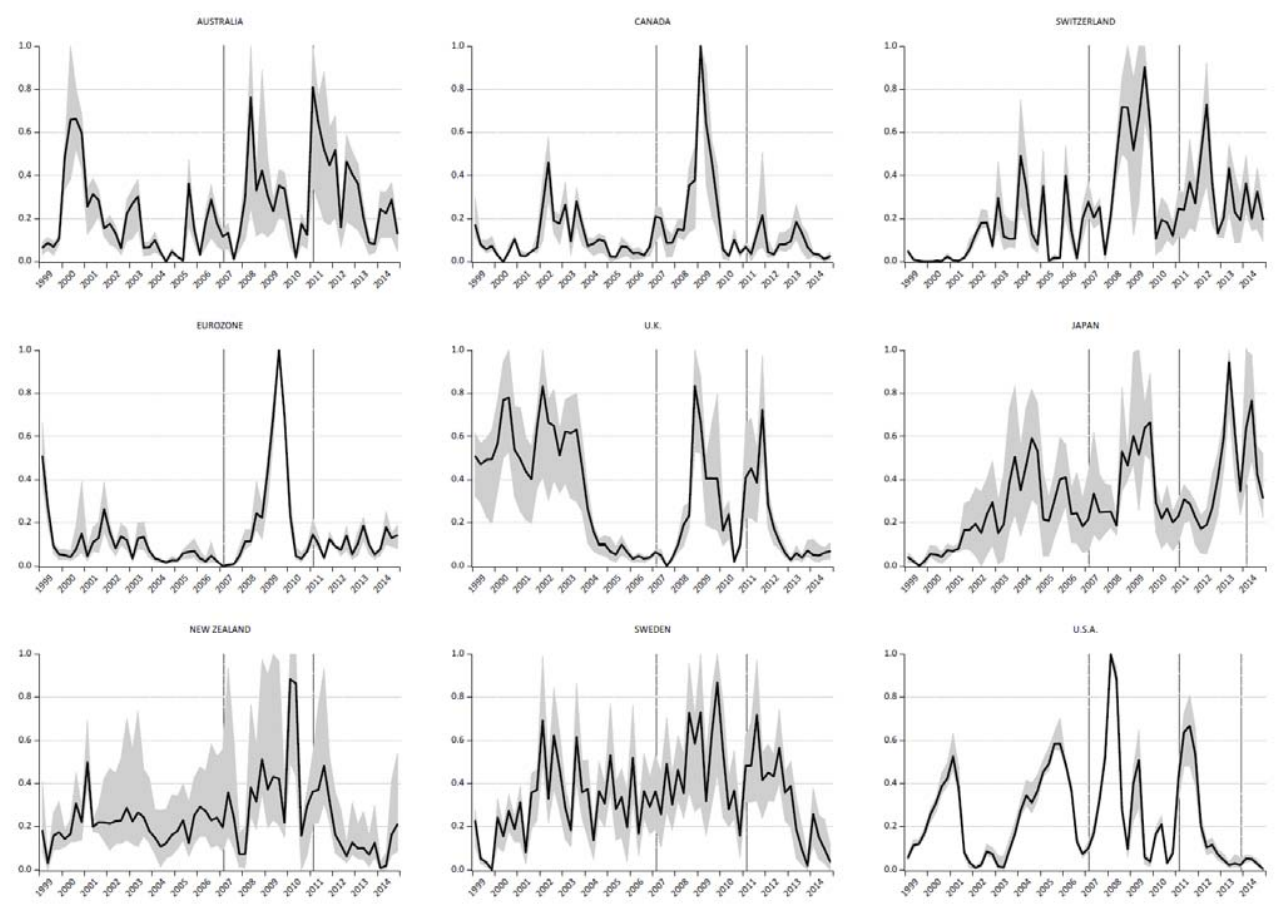
Note: Estimate based on equation (2) applied to all forecast groupings (ALL, all except central bank, central bank only, professionals, public, and households and firms forecasts). For details of each grouping see the main text and the Appendix. 
Figure 5 Inflation Forecast Disagreement: Global
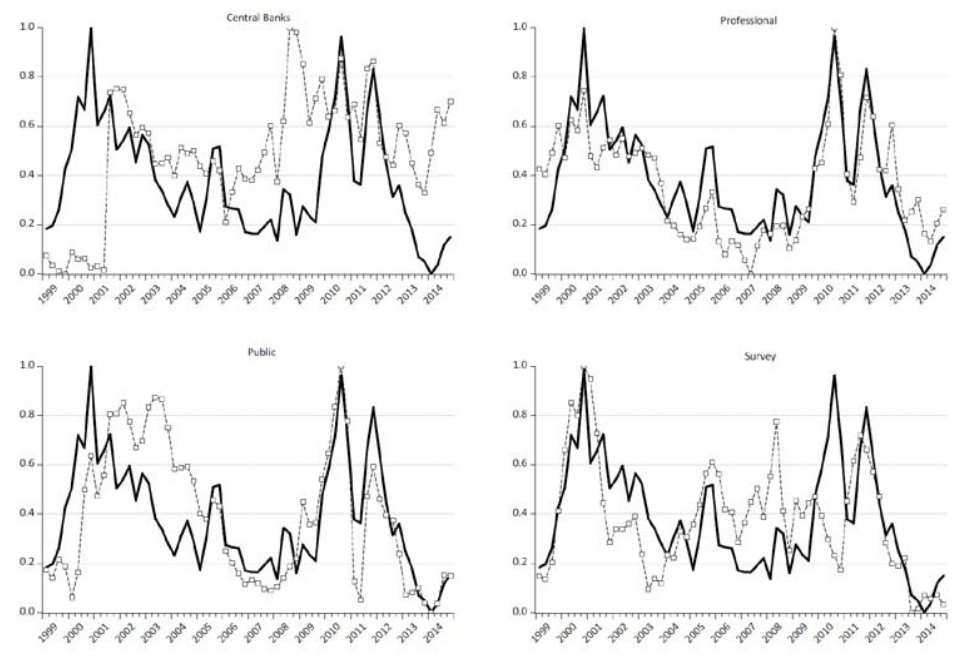

Note: See notes to Figure 3. Equation (2) is used to calculate disagreement by grouping different sources of forecasts across all of the 9 economies in the study. 
Figure 6a Markov Switching Model of Forecast Disagreement: Central Bank Benchmark
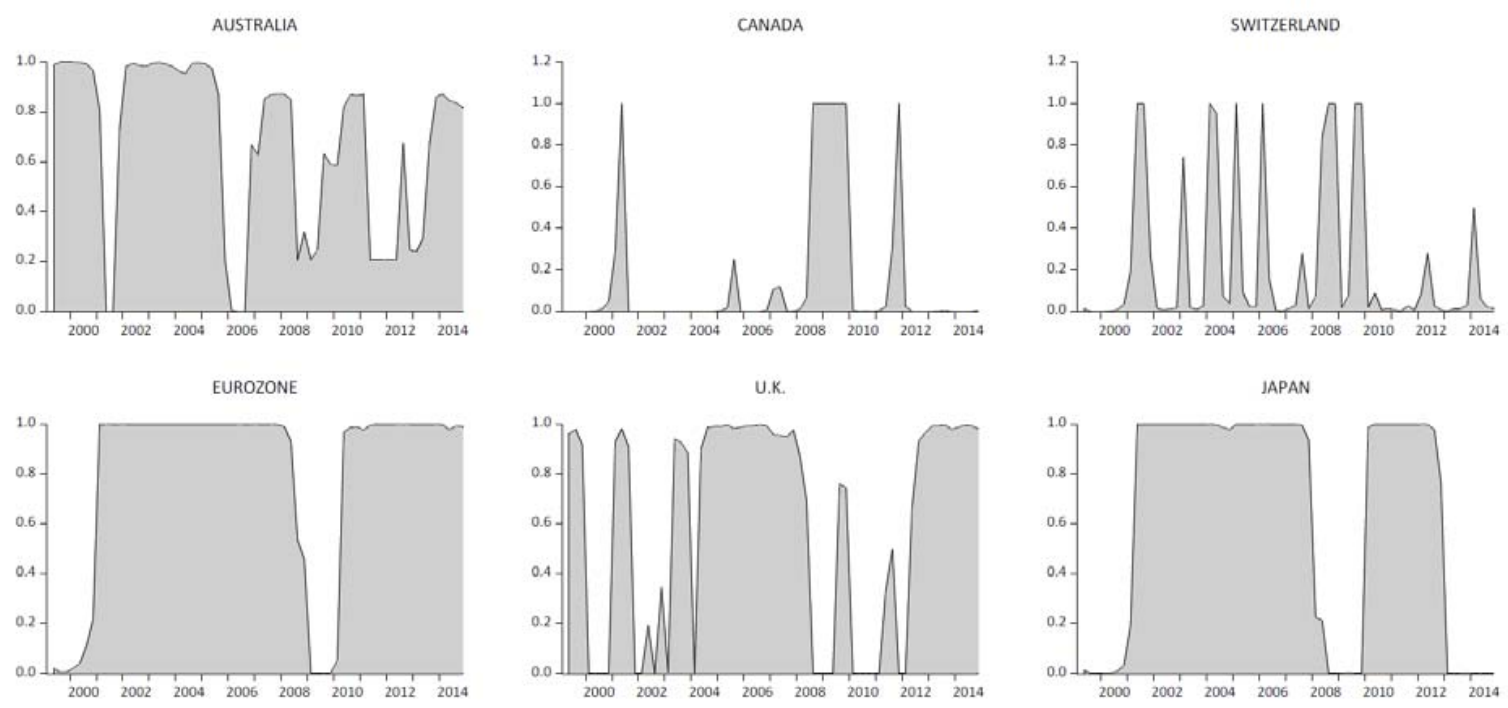

NEW ZEALAND
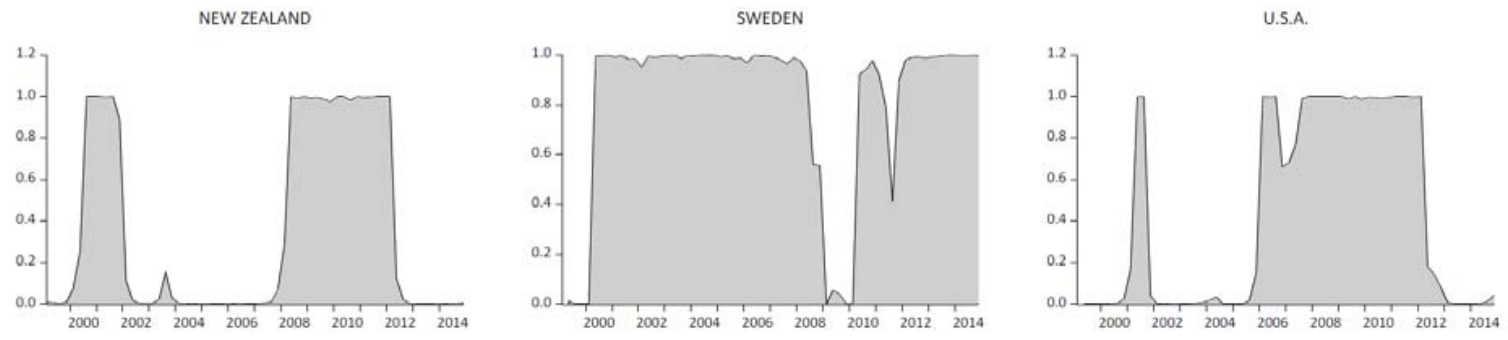

Note: Forecast disagreement is estimated via Markov switching (BHHH optimization method, Huber-White standard errors, Knuth random number generator for starting values) with a constant and regime-specific AR(1) variables, except for Australia, Canada, Switzerland, New Zealand, and Sweden where the AR(1) is not regime-specific and provided a better fit. The title of the Figure indicates the benchmark used to calculate forecast disagreement. 
Figure 6b Markov Switching Model of Forecast Disagreement: Professional Forecasters Benchmark
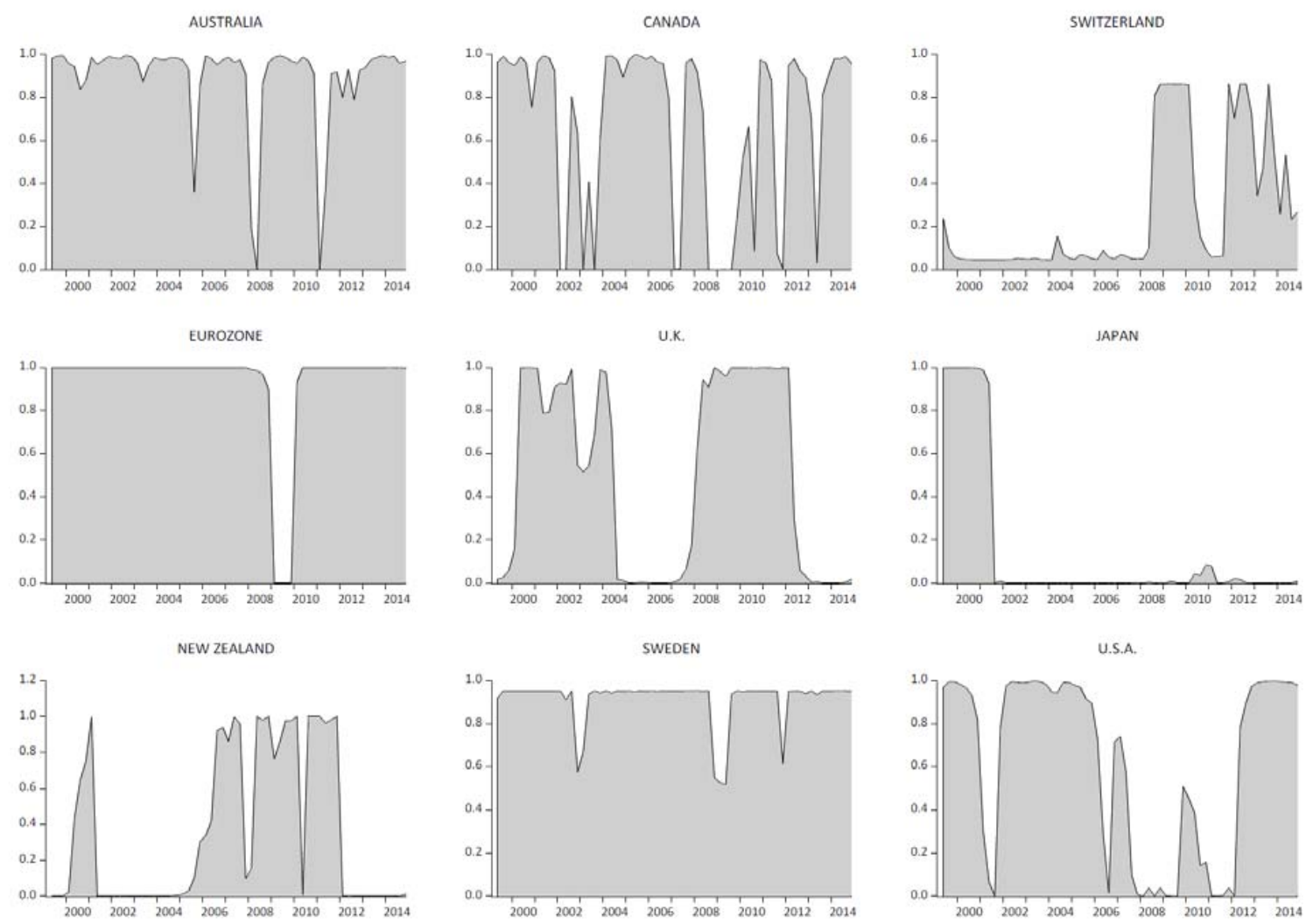

Note: See note to Figure 5a. For Canada, Switzerland, and Sweden, the non-regime-specific AR(1) model provided a better fit. 
Figure 6c Markov Switching Model of Forecast Disagreement: Household and Firms Forecasts Benchmark
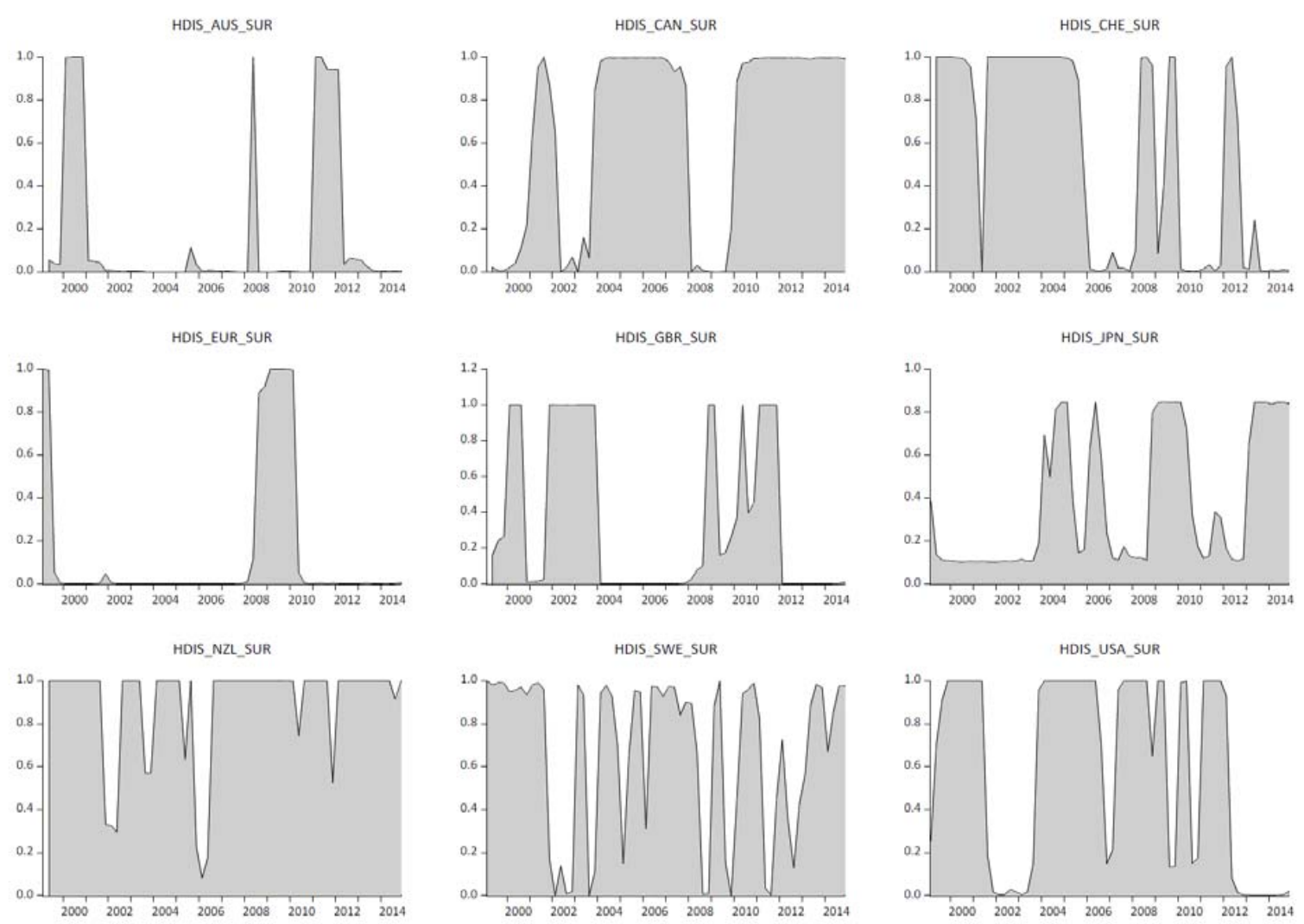

Note: See note to Figure 5a. For Canada, Switzerland, the Eurozone, and the U.S.A. only a constant is included. For Sweden an AR(2) non-regime-specific model provided a better fit. 
References

Alessi, L., E. Ghysels, L. Onorante, R. Peach and S. Potter (2014), “Central Bank

Macroeconomic Forecasting During the Global Financial Crisis: The European Central Bank and the Federal Reserve Bank of New York Experiences”, ECB working paper 1688, July.

Andrade, P., and H. Le Bihan (2013), “Inattentive Professional Forecasters”, Journal of Monetary Economics 60: 967-82.

Aruoba, S.B. and F. Schorfheide (2015), “Inflation During and After the Zero Lower Bound”, paper presented at the Economic Policy Symposium, Federal Reserve Bank of Kansas City, August.

Bachmann, R., S. Elstner, and E.R. Sims (2013), “Uncertainty and Economic Activity: Evidence from Business Survey Data”, American Economic Journals: Macroeconomics 52 (2): 217-49.

Badarinza, C., and M. Buchmann (2009), “Inflation Perceptions and Expectation in the Euro Area”, ECB working paper 1088, September.

Baker, S., N. Bloom, and S. Davis (2016), “Measuring Economic Policy Uncertainty”, Quarterly Journal of Economics (forthcoming).

Ball, L. (1992), “Why does high inflation raise inflation uncertainty?”, Journal of Monetary Economics 29(3), pages 371-388, June.

Bank of England Independent Evaluation Office (2015), “Evaluating Forecast Performance”, November. 
Banternghansa, C., and M. McCracken (2009), “Forecast Disagreement Among FOMC

Members”, Federal Reserve Bank of St. Louis working paper 2009-059A, December.

Bauer, M. (2015), “Inflation Expectations and the News”, International Journal of Central Banking (March): 1-40.

Bekaert, G., M. Hoerova, and M. Lo Duca (2013), “Risk, Uncertainty, and Monetary Policy”, Journal of Monetary Economics 60 (October): 771-788.

Bernanke, B. (2007), “Inflation Expectations and Inflation Forecasting”, speech given at the Monetary Economics Workshop Summer Institute of the National Bureau of Economic Research, Cambridge, July 10.

Bernanke, B., Laubach, T., F. Mishkin and A. Posen (2001), Inflation Targeting: Lessons from the International Experience (Princeton, N.J.: Princeton University Press).

Blinder, A.S., M. Ehrmann, M. Fratzcher, J. De Haan, and D.-J. Jansen (2008), “Central Bank Communiation and Monetary Policy: A Survey of Theory and Evidence”, Journal of Economic Literature 46(4): 910-45.

Boero, G., J. Smith, and K. Wallis (2015), “The Measurement and Characteristics of Professional Forecasters’ Uncertainty”, Journal of Applied Econometrics 30 (November/December): 10291046.

Bordo, M., and P. Siklos (2016), “Central Bank Credibility: An Historical and Quantitative Exploration”, In Central Banks at a Crossroads: What Can We Learn From History? (Cambridge, Mass.: Cambridge University Press), forthcoming. 
Borio, C., and A. Filardo (2007), “Globalization and Inflation: New Cross -Country Evidence on the Global Determinants of Inflation”, BIS working paper 227.

Capistrán, C. and A. Timmermann (2008), “Disagreement and Biases in Inflation Expectations”, Journal of Money, Credit and Banking 41 (March-April): 365-396.

Carlson, J. and M. Parkin (1975), “Inflation Expectations”, Economica 42: 123-138.

Carroll, C.D. (2003), “Macroeconomic Expectations of Households and Professional Forecasters”, Quarterly Journal of Economics 118, 269-288.

Carvalho, C., and F. Nechio (2014), “Do People Understand Monetary Policy?”, Journal of Monetary Economics, 66, 108-123.

Carney, M. (2015), “Inflation in a Globalized World”, speech given at the Federal Reserve Bank of Kansas City Economic Policy Symposium: Inflation Dynamics and Monetary Policy, August 29.

Carney, M. (2015a),’Writing the Path Back to Target”, Given at the Advanced Manufacturing Research Centre, Sheffield, 12 March.

Cecchetti, S., A. Flores-Lagunes, and S. Krause (2006), “Has Monetary Policy Become More Efficient? A Cross-Country Analysis”, Economic Journal 116 (511): 408-433.

Chang, A., and T. Hanson (2015), “The Accuracy of Forecasts Prepared for the Federal Open Market Committee”, Finance and Economics Discussion Series working paper 2015-062, July.

Ciccarelli, M. and B. Mojon (2010), “Global Inflation”, Review of Economics and Statistics 92 (August): 524-535. 
Clements, M., and A.B. Galvão (2014), “Measuring Macroeconomic Uncertainty: U.S. Inflation and Output Growth”, discussion paper 2014-4, University of Reading, May.

Coibion, O., and Y. Gorodnichenko (2015), “Is the Phillips Curve Alive and Well After All? Inflation Expectations and the Missing Deflation”, American Economic Journals: Macroeconomics, 7(1): 197-232.

Constâncio, V. (2015), “Understanding Inflation Dynamics and Monetary Policy, speech given at the Federal Reserve Bank of Kansas City Economic Policy Symposium: Inflation Dynamics and Monetary Policy, August 29.

Diebold, F., and R. Mariano (1995), “Comparing Predictive Accuracy”, Journal of Business and Economic Statistics 13: 253-63.

Dincer, N., and B. Eichengreen (2014), “Central bank transparency and independence: updates and new measures.” International Journal of Central Banking, 10 (1): 189-259.

Dominguez, K., Y. Hashimoto, and T. Ito (2012), “International Reserves and the Global Financial Crisis”, Journal of International Economics, 88 (November): 388-406.

Dovern, J. (2015), “A Multivariate Analysis of Forecast Disagreement: Confronting Models of Disagreement with Survey Data”, European Economic Review 80: 18-35.

Dräger L. (2015), “Inflation Perceptions an Expectations in Sweden - Are Media Reports the Missing Link?”, Oxford Bulletin of Economics and Statistics 77 (5): 681-700.

Dräger L. , M. Lamla (2016), “Disagreement a la Taylor: Evidence from Survey Microdata”, The Scandinavian Journal of Economics (forthcoming). 
Dräger L. , M. Lamla, and D. Pfajfar (2016), “Are Survey Expectations Theory-Consistent? The Role of Central Bank Communication and News”, European Economic Review 85: 84-111.

Draghi, M. (2014), “Monetary Policy in a Prolonged Period of Low Inflation”, Speech at the ECB Forum on Central Banking, Sintra, 26 May.

Drehmann, M. and M. Juselius (2013), “Evaluating Early Warning Indicators of Banking Crises: Statisfying Policy Requirements”, BIS working paper 421, August.

Ehrmann, M., and J. Talmi (2016), “Starting From a Blank Page? Semantic Similarity in Central Bank Communication and Market Volatility”, Bank of Canada working paper 2016-37, July.

Filardo, A., and B. Hoffman (2014), ”Forward Guidance at the Zero Lower Bound”, BIS Quarterly Review, March; 37-53.

Friedman, M. (1977), “Nobel Lecture: Inflation and Unemployment”, Journal of Political Economy 85 (June): 451-472.

Glas, A. and M. Hartmann (2015), “Inflation Uncertainty, Disagreement and Monetary Policy: Evidence from the ECB Survey of Professional Forecasters”, Heidelberg University, February. Haldane, A. (2015), “Drag and Drop”, speech given at the BizClub, Rutland, 19 March. Hamilton, J.D. (2016), “Why You Should Never Use the Hodrick-Prescott Filter”, working paper, University of California, San Diego, November.

Hansen, B., A. Lunde, and J. Nason (2011), “The Model Confidence Set”, Econometrica, 79 (March): 453-497. 
Hart, R., J. Childers, and C. Lind (2013), Political Tone: How Leaders Talk and Why (Chicago: University of Chicago Press).

Hubert, P., and F. Labondance 2017), “Central Bank Statements and Policy Expectations”, Bank of England Staff Working Paper 648.

Hubert, P. (2015), “Do Central Bank Forecasts Influence Private Agents? Forecasting Performance Versus Signals”, Journal of Money, Credit, and Banking, 47 (June): 771-789.

Husted, L., J. Rogers, and B. Sun (2016), “Measuring Monetary Policy Uncertainty: The Federal Reserve, January 1985 - January 2016”, IFDP Notes, 11 April, https://www.federalreserve.gov/econresdata/notes/ifdp-notes/2016/measuring-monetary-policyuncertainty-the-federal-reserve-january-1985-january-2016-20160411.html

Independent Evaluation Office (2013), “IMF Forecasts: Process, Quality, and Country Perspectives” (Washington, D.C. International Monetary Fund), 12 February. International Monetary Fund (2013), “The Dog That Didn’t Bark: Has Inflation Been Muzzled or Was It Just Sleeping?”, World Economic Outlook, Chapter 3, April.

Jurado, K., S.C. Ludvigson, and S. Ng (2015), “Measuring Uncertainty”, American Economic Review 105, 1177-1216.

Kamada, K., J. Nakajima, and S. Nishiguchi (2015), “Are Household Expectations Anchored in Japan?”, Bank of Japan working paper 15-E-8, July.

Koo, (2009), The Holy Grail of Macroeconomics (New York: John Wiley \& Sons).

Kuroda, H. (2015), “What We Know and What We Do Not Know About Inflation Expectations”, luncheon speech at Economic Club of Minnesota, 19 April. 
Lahiri, K., H. Peng, and X. Sheng (2015),’Measuring Uncertainty of a Combined Forecast and Some Tests for Forecaster Heterogeneity”, CESifo working paper 5468, August.

Lahiri, K., and X. Sheng (2008), “Evolution of Forecast Disagreement in a Bayesian Learning Model”, Journal of Econometrics 144: 325-340.

Lombardi, D., P.L. Siklos, and S. St. Amand (2017), “Asset Price Spillovers from Unconventional Monetary Policy: A Global Empirical Perspective”, working paper, Wilfrid Laurier University.

López-Pérez, V. (2014), “Measures of Macroeconomic Uncertainty for the ECB’s Survey of Professional Forecasters”, working paper.

Loughran, T., and B. McDonald (2016), “Textual Analysis in Accounting and Finance: A Survey”, Journal of Accounting Research 54 (September): 1187-1230

Maag, T. (2009), “On the Accuracy of the Probability Method for Quantifying Beliefs About Inflation”, KOF working paper 230, Zürich.

Mackintosh, J. (2015), “There Might Be Trouble Ahead”, Financial Times, 15 October.

Mankiw, N.G., R. Reis (2002), “Sticky Information Versus Sticky Prices: A Proposal to Replace the New Keynesian Phillips Curve”, Quarterly Journal of Economics 117, 1295-1328.

Mankiw, N.G., R. Reis, and J. Wolfers (2003), “Disagreement About Inflation Expectations”, NBER working paper 9796, June. 
Mavroeidis, S., M. Plagborg-Møller, and J. Stock (2014), “Empirical Evidence on Inflation Expectations in the New Keynesian Phillips Curve”, Journal of Economic Literature 52 (March): 124-188.

Mokinski, F., X. Sheng, and J. Yang (2015), “Measuring Disagreement in Qualitative Expectations”, Journal of Forecasting 34 (August): 405-426.

Morris, S., and H. Shin (2002), “Social Value of Public Information”, American Economic Review 52 (5): 1521-1534.

Nishiguchi, S. J. Nakajima, and K. Imabukko (2014), “Disagreement in Households’ Inflation Expectations and Its Evolution”, Bank of Japan Review 2014-E-1, March.

Ng, S. and J. Wright (2013), “Facts and Challenges from the Great Recession for Forecasting and

Macroeconomic Modeling”, Journal of Economic Literature 51 (December): 1120-1154.

Nunes, R. (2013), “Do central banks’ forecasts take into account public opinion and views?” FEDS working paper 1080, May.

Pesaran, H. (1984), “Formation of Inflation Expectations in British Manufacturing Industries” Economic Journal 95: 948-975.

Pesaran, H. (1987), The Limits to Rational Expectations (Basil Blackwell: Oxford).

Reifschneider, and P. Tulip (2007), “Gauging the Uncertainty of the Economic Outlook from Historical Forecasting Errors”, FEDS working paper 2007-60, November. 
Romer, C.D. and D.H. Romer (1989), “Does Monetary Policy Matter? A New Test in the Spirit of Friedman and Schwartz”, NBER Macroeconomics Annual 1989 (Cambridge, Mass.: The MIT Press).

Romer, C.D. and D.H. Romer (2004), “A New Measure of Monetary Policy Shocks: Derivation and Implications”, American Economic Review 94 (September): 1055-84.

Rossi, B. (2014), “Density Forecasts in Economics, Forecasting and Policymaking”, working paper ICREA-Universitate Pompeu-Frabra.

Siklos, P.L. (2016), “Forecast Disagreement and the Inflation Outlook: New International Evidence”, IMES Discussion paper 2016-E-3, Bank of Japan, March.

Siklos, P. (2013), “Sources of Disagreement in Inflation Forecasts”, Journal of International Economics 90: 218-231.

Sims, C. (2015), “Rational Inattention and Monetary Economics”, in Handbook of Monetary Policy, forthcoming (Amsterdam: Elsevier).

Stock, J., and M. Watson (2007), “Why Has U.S. Inflation Become Harder to Forecast?”, Journal of Money, Credit and Banking 39 (S1): 3-33.

Stock, J., and M. Watson (2010), “Modelling Inflation After the Crisis”, in Macroeconomic Challenges: The Decade Ahead (Kansas City: Federal Reserve Bank of Kansas City), pp. 173220.

Stockton, D. (2012), “Review of the Monetary Policy Committee’s Forecasting Capability”, Report to the Court of the Bank of England, October. 
Strohsal, T., R. Melnick, and D. Nautz (2015), “The Time-Varying Degree of Inflation Expectations Anchoring”, Freie University, Berlin, May.

Strohsal, T., and L. Winkelmann (2015), “Assessing the Anchoring of Inflation Expectations”, Journal of International Money and Finance 50: 33-48.

Svensson, L. (2006), “Social Value of Public Information: Comment - Morris and Shin is Actually Pro-Transparency, Not Con”, American Economic Review 96(1): 448-452.

Tetlock, P. (2005), Expert Political Judgment: How Good Is It? How Can We Know? (Princeton, N.J.: Princeton University Press).

Tien, P-L., T. Sinclair, and E. Gamber (2015), “Do Fed Forecast Errors Matter?”, working paper, Novermber.

Timmermann, A. (2006), “Forecast Combinations”, In G. Elliott, C.W.J. Granger, and A. Timmermann (Eds.), Handbook of Economic Forecasting (Amsterdam: Elsevier), pp. 135-196.

Townsend, R. (1983), “Forecasting the Forecasts of Others”, Journal of Political Economy 91 (August): 546-588.

Woodford, M. (2012), “Monetary Policy Accommodation at the Interest-rate Lower Bound”, in (Federal Reserve Bank of Kanas City), pp. 185-288.

Zellner, A. (2002), “Comment on the State of Macroeconomic Forecasting”, Journal of Macroeconomics 24 (December): 499-502.

Yellen, J. (2015), “Normalizing Monetary Policy: Prospects and Perspectives”, speech given At 
the "The New Normal Monetary Policy," a research conference sponsored by the Federal Reserve Bank of San Francisco, San Francisco, California, 27 March.

${ }^{1}$ An alternative approach to communicating forecast uncertainty is via the estimation of density forecasts. This is a separate literature that space limitations prevent me from directly addressing. See, however, Rossi (2014).

${ }^{2}$ The notion that the forecasts of others, not just those published by central banks, may have macroeconomic effects is not new (e.g., see Townsend 1983).

${ }^{3}$ An important consideration in the evaluation of all forecasts, but perhaps especially central bank forecasts, is whether performance is different in the expansionary phase of the business cycle. The answer, at least for the US, seems to be in the affirmative (e.g., see Tien, Sinclair, and Gamber 2015).

${ }^{4}$ The median is another option, of course. However, examination of the individual forecasts suggests that the mean and median are not statistically different from each in the overwhelming number of cases.

${ }^{5}$ While some forecasters can be persistently better than others it is never the case that one forecaster routinely dominates others through time. Indeed, forecasts based on households or firm surveys can do quite well even if the individuals surveyed seemingly have comparatively little expertise (e.g., see Tetlock 2005).

${ }^{6}$ It is well-known, for example, that the mean squared prediction error (MSPE) between the best and the worst forecast need not be statistically significantly different from each other. Hence, forecasting accuracy is not the only characteristic of a forecast that matters.

${ }^{7}$ One should not underestimate the importance central bankers place on anchoring inflation expectations. For example, Yellen (2015) argues “...the presence of well-anchored inflation 
expectations greatly enhances a central bank's ability to pursue both of its objectives--namely, price stability and full employment.” Kuroda (2015) goes so far as to suggest that: "If Japan can successfully overcome deflation and re-anchor inflation expectations, as it is now in the process of doing, this will represent a major step in monetary policy history not only in Japan but also around the globe.” Draghi (2014) also refers to the importance of anchoring in the context of a decline in eurozone inflation: "The firm anchoring of inflation expectations is critical under any circumstances, as it ensures that temporary movements in inflation do not feed into wages and prices and hence become permanent. But it is even more critical in the circumstances we face today.” Carney (2015a) explains why an anchor matters in the following terms: "Those expectations matter as they feed into the wage and price setting processes that ultimately determine inflation. That is why central banks are keenly alert to the possibility that low inflation could de-anchor medium-term inflation expectations, increasing the persistence of inflation.” ${ }^{8}$ There is no precise definition of the 'long-run' but Yellen, in the 16 January 2009 FOMC transcripts, is quoted as saying that the time horizon is longer than six years.

${ }^{9}$ Indeed, forecast dispersion has occasionally also been mentioned as a possible leading indicator of an impending economic slowdown or possible looming crisis (Mackintosh 2015). Indicators of economic policy uncertainty, however, consider only one source of forecast dispersion (e.g., Survey of Professional Forecasters).

${ }^{10}$ Siklos (2013) provides a brief survey of the literature that deals with forecast disagreement, its measurement (also see section 3 below) that is up to date until 2010. Below I focus on the evidence and issues that have received attention since then.

${ }^{11}$ They also consider the 'noisy' information model wherein forecasters update their outlook subject to imperfect access to the relevant data. 
12 The Institute for Economic Research housed at the University of Münich.

${ }^{13}$ This development has partly been encouraged, as noted earlier, by the creation of an index of economic policy uncertainty. See Baker et. al. (2016) and http://www.policyuncertainty.com/.

${ }^{14}$ Although such a conclusion is more likely to be reached for professional and central bank forecasts than for households' forecasts of inflation. See, for example, Ng and Wright (2013), IEO (2014) and Mavroeidis et. al. (2014) who review the issues.

${ }^{15}$ For example, details about the probabilistic structure that underlies forecasters' outlook play a role (i.e., the definition of the bins, or categories, expectations fall into).

${ }^{16}$ To the extent that more individual's expectations become anchored this ought to reduce forecast disagreement. See Badarinza and Buchmann (2009) for evidence from the Eurozone. ${ }^{17}$ Shortly after the appointment of Governor Kuroda at the Bank of Japan the central bank announced its determination to meet a $2 \%$ inflation target. The original intention was to achieve the target within 2 years. However, the sharp drop in oil prices in 2014 has forced the Bank to delay meeting this objective.

${ }^{18}$ Economies examined were the U.S., the Eurozone, U.K., and Sweden.

${ }^{19}$ Their evidence is primarily based on the University of Michigan Survey data. A general problem with some survey data is that inflation is often not clearly defined and participants must often respond with a forecast to the nearest integer.

${ }^{20}$ In recognition that in a few instances some policy rates have become negative.

${ }^{21}$ This is the so-called “Dog That Didn’t Bark” (IMF 2013) that continues to pre-occupy policy makers.

${ }^{22}$ That study only examines how central bank forecasts influence Consensus forecasts. Siklos (2013) considers their influence on a broader set of forecasts. Aruoba and Schorfheide (2015) 
also indicate that the issue whether private agents and central bank forecasts can have the appearance of being coordinated is an important one for our understanding of the dynamics of inflation.

${ }^{23}$ This potentially adds some 'noise' to the interpretation of the results for at least two reasons. First, some central banks (e.g., the Fed) may target a different price index (e.g., the Personal Consumption Expenditures or PCE index) while all central banks tend to be more concerned with a measure of core inflation (i.e., one that typically strips food, energy and indirect taxes). Since, as noted earlier, judgment also influences forecasts the various benchmarks considered may not be perfectly comparable.

${ }^{24}$ The measure used here comes closest to the one used in Lahiri and Sheng (2008) while the transformation applied yields a version that is the normalized absolute deviation of forecasts implemented by Banternghansa and McCracken (2009). Forecast disagreement is sometimes also evaluated, for example, by calculating the inter-quartile range of forecasts (e.g., Mankiw, Reis, and Wolfers (2003), Capistrán and Timmermann (2008)). The indicator used here has the virtue of retaining all the available information.

${ }^{25}$ There is, of course, no unique normalization but the estimates of $d_{t h}^{j}$ discussed below are bounded between $[0,1]$ (i.e., using the transform $\left(d-d_{\min }\right) /\left(d_{\max }-d_{\min }\right)$.

${ }^{26}$ In an earlier version some proxies for forecast uncertainty were generated for U.S. data and these support the contention of Boero et. al. who examine U.K. data. Both Lahiri et. al. (2015), and Boero et. al. (2014), show that the variance of (density) forecasts is the sum of average individual uncertainty and a measure of the dispersion, or disagreement, between individual density forecasts. The first element is generally unobserved. 
${ }^{27}$ Consider a monthly forecast of inflation $(\pi)$ for calendar year $t$, released in month $m$ (with quarterly date we replace 12 months with 4 quarters per year). Denote such a forecast as $\pi_{m, t}^{F E}$ where FE refers to the fixed event nature of the forecast. Hence, a forecast for the fixed event one year ahead would be written $\pi_{m, t+1}^{F E}$. The transformation from FE to FH, where FH represents a fixed horizon forecast, is $\pi_{\mathrm{m}, \mathrm{t}}^{\mathrm{FH}}=[(13-\mathrm{m}) / 12] \pi_{\mathrm{m}, \mathrm{t}}^{\mathrm{FE}}+[(\mathrm{m}-1) / 12] \pi_{\mathrm{m}, \mathrm{t}+1}^{\mathrm{FE}}$.

${ }^{28}$ Essentially, this fits a local quadratic polynomial for each observation of the low frequency series. This polynomial is then used to fill in the missing observations at the higher frequency.

${ }^{29}$ The ECB aims for inflation in the Harmonized Index of Consumer Prices (HICP) of “...a yearon-year increase in the Harmonized Index of Consumer Prices (HICP) for the euro area of below 2\%”, https://www.ecb.europa.eu/mopo/strategy/pricestab/html/index.en.html. The BoJ’s objective has changed over time although its mandate has been to achieve some form of price stability. The $2 \%$ objective has been made more explicit, however, since the appointment of Governor Haruhiko Kuroda in 2013. See https://www.boj.or.jp/en/announcements/release_2013/k130122b.pdf. The SNB defines price stability as “...a rise in consumer prices of less than $2 \%$ per year.” See http://www.snb.ch/en/iabout/snb/id/snb_tasks. Finally, the Fed, under Chairman Bernanke declared in 2012 that “... inflation at the rate of 2 percent (as measured by the annual change in the price index for personal consumption expenditures, or PCE) is most consistent over the longer run with the Federal Reserve's statutory mandate.” (http://www.federalreserve.gov/faqs/money_12848.htm). Nevertheless, many have argued that a 2\% medium-term objective was effectively adopted under Alan Greenspan’s chairmanship of the FOMC. 
${ }^{30}$ A separate appendix, available on request, but also see Siklos (2016) who provides the details.

${ }^{31}$ Both the standard two-sided gap and a one-sided gap were estimated. The empirical results rely on the one-sided gap measure. The global output gap measure is constructed as in Borio and Filardo (2007). Since the chapter was written Hamilton (2016) has persuasively argued that none of the variants of the H-P adequately fulfill their objective. Future research may well conclude that the output gap has more, or less, of an impact on forecast disagreement if it is measured in the manner proposed by Hamilton (2016).

${ }^{32}$ It is common for central banks to make the distinction between the two inflation indicators especially as they are not likely to respond to supply side shocks unless these feed into expectations while demand side shocks typically elicits a response.

33 The data were obtained from http://www.cboe.com/micro/vix/historical.aspx. I also considered, where available, the economic policy uncertainty index (i.e., for the U.S.A., Europe, Canada, and Japan) due to Baker et.al. (2016) and the results are largely the same as the ones described below.

${ }^{34}$ The Reserve Bank of Australia forecasts were excluded from Siklos (2013). A total of 74 forecasts were used in Siklos (2013). Hence, the number of forecasts has risen by approximately $12 \%$ relative to that study.

${ }^{35}$ For example, see Filardo and Hoffman (2015) for a critical review of forward guidance practices.

${ }^{36}$ There exist several algorithms that attempt to evaluate the content of documents. Others that have been used by economists included Wordscores, Leximancer, and General Inquirer, to name three. 
${ }^{37}$ This is based on the metric developed by Chand et. al. (2010). Of course, the choice of 10 words is arbitrary and the selection of ideas that are grouped together is also dictated by the chosen language quantification algorithm. As noted by Loughran and McDonald (2016), there is no unique normalization. However, it is essential to normalize because text length (and complexity) can vary considerably.

${ }^{38}$ By default, DICTION classifies words in a document according to the following characteristics. They are: certainty, that is, a collection of words indicating resoluteness; optimism, namely language that endorses a position or a concept; activity, such that the words suggest ideas or stances being implemented and that inertia is avoided; realism, meant to inform the reader of tangible results or recognizable facts; and, finally, commonality, that is, language that draws attention to common values or positions in a text. Examples of words that are 'positive’ include ‘consensus’, ‘successful'; negative words would include ‘apprehension', and 'detrimental'. Lombardi et. al. (2017) use a modified classification but provide more examples of words that can be construed as positive or negative.

${ }^{39}$ One of many examples that come to mind is the U.S. Federal Reserve dropping the word “patient” in its press releases in mid-2015.

${ }^{40}$ It is possible, at the quarterly frequency, that some forecasters (e.g., central banks) have information for some variables at time $t$. However, even in this case, since forecasts involve judgment it is not necessarily the case that the most current information will affect inflation forecasts. In any case as a sensitivity test, I also estimate equation (3) with the right hand side variables entering with a lag and the conclusions are unaffected. Although there is some serial correlation in inflation forecasts disagreement it is modest and, often, statistically insignificant (results not shown). 
${ }^{41}$ Given the length of the sample I also experimented with time-varying common factor in a rolling fashion with windows that range from 2 to 5 years in length and the results were little changed.

${ }^{42}$ As noted above the specifications reflect a preference for parsimony partly due to the sampling frequency of the data. Nevertheless, the conclusions are broadly similar if more conventional variables (e.g., term spread, asset prices, nominal effective exchange rates) are used instead and the variables expressed as differentials enter individually.

${ }^{43}$ Bekaert et. al. (2013) find that the VIX can be decomposed into an uncertainty component as well as a risk aversion component. Moreover, they conclude that there is a strong empirical connection between how loose monetary policy is and the VIX. Of course pre-crisis, loose monetary policy was a harbinger of higher inflation but, since the crisis, this no longer appears to be the case since financial stability considerations loom larger.

${ }^{44}$ I also included a dummy variable for unconventional monetary policy actions in the US and this variable proved statistically insignificant in the overwhelming number of cases. The dummies, set to 1 when a policy action is announced and 0 otherwise, accounts for the launch of QE1 (November 2008-March 2009), QE2 (November 2010), and the tapering of bond purchases in 2014.

${ }^{45}$ An anonymous referee has correctly pointed out that netting the positive and negative elements of tone may also have played a role in the results obtained. This is no doubt correct but the estimated specification partly reflects the need to conserve degrees of freedom. In any event, netting out the two elements of tone can also be justified by noting that most central bank statements are likely to contain both positive and negative words. Also, central banks may be biased away from the use of negative words for fear of spreading undue fear in financial markets 
especially. Finally, the relative importance of the change in tone may also be influenced by the chosen benchmark. One could have instead evaluated the change in tone relative, say, to the mean of positive and negative characteristics in central bank announcements obtained in a preGFC sample. Alternatively, one might have included a measure of the similarity of central bank press releases over time. However, it is unclear whether the level or variance of forecast disagreement may be affected. See Ehrmann and Talmi (2016). These kind of extensions are also left for future research.

${ }^{46}$ When some of the other variants of the communication variable shown in Table 2 are used there are a few other cases where the variable is found to be statistically significant (Switzerland, U.K., and Sweden).

${ }^{47}$ There may be more than one Markov-switching model to describe forecast disagreement regimes. However, we do know from the large literature on inflation persistence, that it is a function of the policy regime in place. Since the AR(1) parameter is a summary indicator of inflation persistence it is reasonable to assume that this parameter differs by regime.

${ }^{48}$ Hubert and Labondance (2017) report that the content of central bank statements influences financial market expectations over and above the effects of monetary policy decisions and central banks forecasts.

${ }^{49}$ Equation (3) was also estimated by replacing oil price inflation (largely insignificant in the vast majority of estimated regressions) with a recession dummy (NBER for the USA, CEPR for the Eurozone, C.D. Howe Institute for Canada, and the Economic Cycle Research Institute's dating scheme for the remaining economies considered. Some evidence that forecast disagreement is higher is found for Canada, the Eurozone, Sweden and the USA but not for the other economies examined. 